\title{
The US Crime Puzzle: A Comparative Perspective on US Crime \& Punishment
}

\section{Citation}

Holger Spamann, The US Crime Puzzle: A Comparative Perspective on US Crime \& Punishment, (The Harvard John M. Olin Discussion Papers, No. 778, 2014).

\section{Published Version}

http://www.law.harvard.edu/programs/olin_center/papers/pdf/Spamann_778_1.pdf

\section{Permanent link}

http://nrs.harvard.edu/urn-3:HUL.InstRepos:16162404

\section{Terms of Use}

This article was downloaded from Harvard University's DASH repository, and is made available under the terms and conditions applicable to Open Access Policy Articles, as set forth at http:// nrs.harvard.edu/urn-3:HUL.InstRepos:dash.current.terms-of-use\#OAP

\section{Share Your Story}

The Harvard community has made this article openly available.

Please share how this access benefits you. Submit a story.

Accessibility 


\section{HARVARD}

JOHN M. OLIN CENTER FOR LAW, ECONOMICS, AND BUSINESS

\section{THE US CRIME PUZZLE: A COMPARATIVE PERSPECTIVE ON US CRIME \& PUNISHMENT \\ Holger Spamann}

Discussion Paper No. 778

$07 / 2014$

Harvard Law School

Cambridge, MA 02138

This paper can be downloaded without charge from:

The Harvard John M. Olin Discussion Paper Series: http://www.law.harvard.edu/programs/olin_center/

The Social Science Research Network Electronic Paper Collection: http://ssrn.com/abstract=2463720 


\title{
The US Crime Puzzle: A Comparative Perspective on US Crime \& Punishment
}

\author{
Holger Spamann ${ }^{1}$ \\ Harvard Law School
}

September 10, 2014

\begin{abstract}
${ }^{1}$ hspamann@law.harvard.edu. Predecessors of this draft circulated under various titles. I am grateful to David Abrams, Ruchir Agarwal, Tania Diaz Bazan, Lucian Bebchuk, Bernard Black, John Donohue, Jeffrey Fagan, Andreas Fuster, Martin Gelter, Stefano Giglio, Yehonatan Givati, Edward Glaeser, Andrew Hammel, Louis Kaplow, Dan Klerman, Justin McCrary, Eduardo Morales, Nathan Nunn, Mark Ramseyer, Mark Roe, Andrei Shleifer, Tom Vogl, Crystal Yang, and workshop participants at Harvard University, Stanford University, the University of Bonn, the University of Chicago, the University of Hamburg, the University of Texas at Austin, and the 2009 Annual Meeting of the American Law and Economics Association (San Diego), and the Fourth Annual Conference on Empirical Legal Studies (Los Angeles 2009) for helpful comments and suggestions, and to Dominika Sarnecka for research assistance. Thanks to John van Kesteren and Gallup Europe for granting me access to the ICVS and EUICS data, respectively, to Tom Ginsburg for access to data from the Comparative Constitutions Project, to Kathleen Maguire for access to tables from the Sourcebook of Criminal Justice Statistics, and to Roy Walmsley for making early editions of the World Prison Population List available to me. I gratefully acknowledge financial support from a Terence M. Considine Fellowship in Law and Economics provided through the John M. Olin Center for Law, Economics, and Business at Harvard Law School.
\end{abstract}




\begin{abstract}
I generate out-of-sample predictions of US crime and incarceration rates from cross-country regressions. Predictors suggested in the literature explain a large part of the international variation, but fail to explain the US. The US incarceration rate is four times higher than predicted, while US crime rates are at best slightly below the prediction. An explanation of this US crime puzzle requires a low crime-punishment elasticity at US levels of punishment, or a major omitted factor pushing the US latent crime rate far above the prediction. I derive joint bounds for the two. Drawing on additional country-specific information, I argue that the most plausible explanation combines both elements.
\end{abstract}




\section{Introduction}

The United States (US) incarcerates more people per capita than any other country in the world, and 5 times and 4.5 standard deviations more than the average OECD country (Walmsley 2012). If the US were like other OECD countries in all respects except punishment per crime, US crime should be concomittantly lower. ${ }^{1}$ For example, if the elasticity of crime with respect to the prisoner population were -0.4 as estimated in Levitt (1996) for violent crime, incarcerating five times more people would reduce crime by half. Even if the elasticity were only around -0.15, as estimated in Johnson and Raphael (2012), crime would decrease by $24 \%$. In reality, crime rates in the US are high. As shown in figures 1 and 2, within the OECD, the US is a high outlier for homicides and serious drug abuse, and at least above the median for other crimes. I call this the US crime puzzle.

The question I address in this paper is whether these numbers can be reconciled by making allowance for other US peculiarities. Such peculiarities may increase US latent crime relative to other OECD countries. By latent crime, I denote the (unobservable) level of crime that would prevail at some hypothetical uniform level of punishment per crime. For example, the US also has the highest income inequality (OECD 2013) and teen birth rates (Kearney and Levine 2012) among Western OECD countries, both of which increase (latent) crime (Fajnzylber et al. 2002; Messner et al. 2002; Hunt 2006). This paper's estimates suggest, however, that the effects of these and other commonly discussed factors are not large enough to reconcile the comparative data with sizeable elasticities of crime with respect to the part of US incarceration that exceeds the OECD average.

Concretely, I compare actual US crime and incarceration rates to predictions from crosscountry regression models. The regressions include all main exogenous cross-country predictors identified in the literature, and are estimated on the largest possible cross-country sample excluding the US. ${ }^{2}$ To obtain unbiased coefficients for the exogenous predictors, the regressions are in reduced form, i.e., the crime regressions do not control for any aspects of punishment and vice versa. Crime and incarceration rates are functions of expected punishment, latent crime, and the crime-punishment elasticity. Hence for any given elasticity, the reduced form residual rates - i.e., the differences between predicted and actual rates - can be analytically decomposed into residual punishment and residual latent crime. I use this decomposition of US residuals to derive bounds on residual latent US crime as a function of the assumed elasticity.

Predicted crime and incarceration rates in the US are high, due inter alia to high US

\footnotetext{
${ }^{1}$ Another condition of this prediction is that crime be inelastic with respect to expected prison time. This is commonly assumed in the theoretical literature, and borne out by all empirical evidence that I am aware of.

${ }^{2}$ In practice, I combine the estimation and prediction steps by including the US in the sample but inserting a US dummy. The coefficient on the dummy is algebraically identical to the difference (between the prediction and actual US rates) one would obtain in two steps.
} 
inequality and teen birth rates. The actual US incarceration rate is still four times higher than predicted, however, while US crime rates are at best slightly below the prediction. Even at the lower $95 \%$ confidence bound of estimation error, residual US rates are incompatible with a constant crime-punishment elasticity below -0.27 for smaller crimes and any negative elasticity for homicides, except to the extent an omitted factor drives US latent crime above the (implicit) prediction.

The preceding statement of the paper's main finding contains two important limitations. First, it only rejects constant crime-punishment elasticities of a certain size, and thus implicitly certain claims about the effectiveness of US mass incarceration. Crime may be much more elastic at lower levels of punishment.

Second, the paper's contribution is to eliminate most competing explanations of the US crime puzzle; it cannot eliminate all of them. The main quantitative analysis rules out linear forms of most explanations commonly offered in the comparative literature, such as political structure, inequality, or ethnic fractionalization including the legacy of slavery. ${ }^{3} \mathrm{~A}$ robustness check provides evidence against nonlinear effects and interactions of these factors. The discussion part excludes certain other explanations, such as deinstitutionalization of the mentally ill. While the list of remaining possible explanations is in principle open-ended, the list of plausible ones is probably short. I discuss suggestive evidence in favor of neighborhood segregation and against the number of guns as explanations. Narrowing the field in this way can have considerable benefits for directing further research and disciplining policy discussion.

Most modern econometric work on crime avoids or at least reduces the problem of confounding factors by considering quasi-experimental settings. There are at least two reasons, however, to complement the quasi-experimental studies with an observational macro perspective. First, micro studies cannot identify macro effects such as neighborhood disruption or the removal of stigma effects (McCrary and Sanga 2012). Second, (quasi-)experiments trade off high internal validity for possibly low external validity (e.g., Rodrik 2009). One manifestation of this is that estimates of local average treatment effects of punishment vary widely, from close to zero (Helland and Tabarrok 2007, Lee and McCrary 2009, Abrams 2012) to rather large (Levitt and Kessler 1999 and Drago et al. 2009 on deterrence; Owens 2009, Buonanno and Raphael 2013, and Barbarino and Mastrobuoni 2014 on incapacitation; Buonnano et al. 2011 on imprisonment generally). An observational study can help triangulate which of the estimates is more representative, at least after taking into account macro effects. In particular, the present study suggests that the low estimates, which are all from US settings, are more representative of the US situation than the high estimates, many of

\footnotetext{
${ }^{3}$ Theoretically, even this statement is too broad. The omission of other variables in the regression models - relative to the "true" causal model - may bias the coefficients of the included variables. In theory, this bias could be so large as to be responsible for the entire US residuals. I regard this possibility as implausible.
} 
which come from Europe.

To perform such triangulation on comparative data, a large sample of countries commends itself for three reasons. First, only a large sample offers enough degrees of freedom for all predictors identified in the literature. Second, only a large sample offers sufficient variation in the predictive variables to avoid the worst forms of extrapolation. For example, to apply estimates of the effect of inequality from only a sample of rich Western countries to the US would necessarily extrapolate beyond the estimation support for this variable. Put differently, in many respects a small sample of rich Western countries is not a good comparison for the United States. Third, most comparative theories regarding crime and punishment have been developed and tested on essentially the same small group of rich countries. Extending the sample is important to assess the validity of these theories, or more to the point, to avoid over-fitting and to build a reliable model for predicting US rates. To maintain the sample size and avoid bias from non-randomly missing values, I use various techniques to deal with missing data, with essentially identical results.

The main downside of large samples is that there is less detailed data available. In particular, there is no data on the composition of the incarceration rate, i.e., sentence length vs. frequency of new admissions, and which crimes inmates are serving time for. By considering a broad spectrum of crime, however, I leave little room for the possibility that the results are driven by some omitted type of crime that the US would (successfully) target very severely at the expense of raising its incarceration rate. Data on other dimensions of punishment, such as prison conditions, are also lacking at the large sample level. The latter only biases my results against my ultimate finding, however. Prison conditions and other non-time aspects of punishment, such as shaming or the death penalty, are by all accounts unusually harsh in the US by Western standards, and generally positively correlated with the incarceration rate (e.g., Tonry 2001; Whitman 2003, 2005; Tonry and Melewski 2008). In any event, I address many of these issues in the discussion.

The papers closest to the present one are Dills et al. (2010) and McCrary and Sanga (2012). They compare changes in crime and punishment in the US with those in a small number of other countries. McCrary and Sanga assume parallel latent crime trends (cf. Durlauf 2012), and conclude that the five-fold increase in US incarceration since the early 1970s reduced crime modestly at best. Dills et al. juxtapose changes in a handful of background characteristics and crime policy, and argue that no clear patterns emerge. Buonnano et al. (2011) also use data from multiple countries, but allow for flexible, unobserved country-specific trends to estimate a crime-incarceration elasticity of -0.4 from shocks to imprisonment (amnesties) that they argue are uncorrelated with latent crime. In line with other comparative economic work on crime (e.g., Soares 2004, Lin 2007), these analyses thus eliminate time-invariant heterogeneity to identify causal effects of time-varying variables. By 
contrast, I focus precisely on the much larger cross-country differences in levels. ${ }^{4}$ Moreover, my reduced form regressions themselves merely sharpen the US crime puzzle; they do not directly estimate the effects of crime and punishment on one another (which would not be identified for lack of a credible instrument ${ }^{5}$ ). I address punishment's effect on crime only indirectly and only for the contemporary US. To be precise, I analyze only the part of US punishment (and crime) that exceeds the comparative prediction. For this limited question, I can also draw on qualitative information for the US.

Methodologically, the paper is part of a much broader comparative literature that attempts to gain insights from "synthetic" counterfactuals constructed from comparative data. That is, this paper extends the approach of comparing the US to one similar country, usually Canada (e.g., Cook and Khmilevska 2005), to a model-based comparison that allows for closer approximation of the relevant covariates. Abadie et al. (2010) formalize this method in a panel setup that can deal with unknown factor loadings and avoid extrapolation. For lack of data and a clearly defined treatment, this method is unavailable here.

The paper proceeds as follows. Section 2 describes the data. Section 3 explains the regression setup, in particular the handling of missing data. Section 4 presents the results, including robustness to model specification and over time. Section 5 derives joint bounds on the crime-punishment elasticity and residual US latent crime. Section 6 discusses the plausibility of various explanations. Section 7 concludes.

\section{$2 \operatorname{Data}^{6}$}

I now describe the data used in this paper. Figures 2 and 3 show the US values, global distributions, and OECD distributions for all the dependent and independent variables, respectively.

\subsection{Dependent variables}

The choice of four dependent variables is dictated by the need to achieve considerable country coverage without sacrificing too much in terms of reliability.

\footnotetext{
${ }^{4}$ The cross-country standard deviation is at least twice as large as the within-country standard deviation for key variables such as the incarceration rate, the homicide rate, income inequality, or teen births.

${ }^{5}$ As shown in the appendix, all variables structurally affecting one plausibly also affect the other, violating the exclusion restriction. The one possible exception is demographics, in particular the share of young males, which could plausibly be structurally unrelated to punitiveness. It would be a weak instrument, however, and being correlated with the distribution of crime types, it would be correlated with the measurement error in any punishment-per-crime variable that one could construct from generic incarceration divided by specific crime rates.

${ }^{6}$ I merge Guernesey and Jersey into Channel Islands, and England and Wales, Northern Ireland, and Scotland into the UK.
} 


\subsubsection{Crime}

Reliably measuring crime is notoriously difficult, since much crime is not reported. Importantly, the propensity to report crime covaries with certain variables of interest, such as the level of development or inequality (Soares 2004), and is not constant over time (Gibson and Kim 2008; Vollaard and Hamed 2012). Police-reported official crime data will thus paint a very misleading comparative picture. ${ }^{7}$ INTERPOL (1999) explicitly warns against using its data for comparative purposes.

There are three series of crime data available for large cross-sections, however, that are considered reliable, and I use all of them in this paper.

Homicide rates (WHO/GBD). The first is the homicide rate, as homicides are difficult to conceal. There are two comparative data series in wide use: data from police statistics as compiled by the United Nations Office on Drugs and Crime (UNODC), and data primarily from death classifications by medical practitioners compiled by the WHO (Newman and Howard 1999). I use the latter because the former contain many clear reporting errors and cover less than two thirds as many countries. ${ }^{8}$ In the main cross-sectional tests, I use a recent overhaul of the WHO Global Burden of Disease (GBD) data for 2005, which offers the highest data quality and country coverage $(N=187)$ (IHME 2013). For the subsequent discussion of time trends, I also use the other two years of updated GBD data (1990 and 2010), and data from the standard WHO mortality database available since the $1960 \mathrm{~s} .{ }^{9}$ The correlation between the log-transformed GBD and WHO rates is 0.85 .

Different years of the standard WHO data were collected under different versions of the International Classification of Diseases (ICD). Accordingly, the definition of "homicides" (in truth, a composite of a variety of smaller categories) is not constant in decades past. To account for this, I include dummies for each version of the ICD when using the standard WHO data.

\footnotetext{
${ }^{7}$ For example, Buannano et al. (2011, web appendix) show that relatively low reporting rates in the US bias US police-reported crime rates downwards relative to other wealthy countries. Even domestically, police reported data can be misleading. For example, more reliable victimization data show a break in US crime trends much earlier and more dramatically than police reports. Cf. US Department of Justice, Office of Justice Programs, Office of Victims of Crime, 2013 National Crime Victims' Rights Week Resource Guide, section 6, pp. 4-7, available at http://www.victimsofcrime.org/docs/ncvrw2013/2013ncvrw_stats_crimetrends.pdf?sfvrsn=0 (visited $4 / 27 / 2014)$.

${ }^{8}$ In particular, many countries' values jump by an order of magnitude from one year to the next, or diverge by up to an order of magnitude from domestic statistics. In any event, I have verified that the US results would not change with the UNODC homicide data.

${ }^{9} \mathrm{http}: / /$ www.who.int/healthinfo/mortality_data/en/. In fact, the WHO provides some data even in the 1950s, but data on key independent variables, particularly the Gini coefficient and teen birth rates, is not available for those years.
} 
Victimization rates for common crimes (ICVS). The second reliable series of comparative crime data come from victimization studies, i.e., representative surveys eliciting experiences of victimization by various crimes (Tonry and Farrington 2005; Lynch 2006). Standardized comparative data on ten common property and contact crimes have been collected in five sweeps of the International Crime Victims Survey between 1989 and 2005, including the European Survey on Crime and Safety (van Dijk et al. 2007; van Kesteren 2007) (hereinafter collectively referred to as ICVS). As my interest is in country-level determinants, following Wooldridge (2003) I work with weighted country-level averages rather than individual data. ${ }^{10}$

The major shortcoming of the ICVS data is low coverage in any given sweep. Although 75 countries participated in at least one of the five sweeps, any given sweep covered far fewer. For example, the 2004-05 sweep contained only 27 country surveys (essentially all and only OECD countries). Consequently, papers using these measures in the past have had only about 40 observations to work with (e.g., Soares 2004). To my knowledge, I am the first to pool data from all five sweeps, including city surveys from developing countries, which gives me 75 countries or around 300,000 individual responses (after eliminating duplicates) to work with. (I take appropriate steps to adjust for the unbalanced nature of the data, see Section 3.2 below.)

I primarily use the one-year prevalence rate of victimization by nine common crimes (burglary; attempted burglary; personal theft; theft of a car, theft from a car; theft of a bicycle; theft of a motorcycle; assault; and robbery), i.e., the probability of being the victim of any of these nine crimes at least once in the year before the survey. ${ }^{11}$ This measure is commonly emphasized in the comparative literature as a proxy for overall crime (e.g., van Dijk et al. 2007), it has sufficiently many non-zero individual observations to estimate country averages reliably, and its focus on less serious crimes provides a useful counterpoint to the homicide measure. Peru and Tanzania lack information on at least one of these crimes, and I omit them. This leaves me with 73 countries with observations for at least one sweep. I also show results for major component crimes.

Drug use prevalence and death rates (WDR/GBD) Finally, I use the GBD measure of deaths caused by drug-use disorders in 2005. As noted above, the GBD measures are considered very reliable. To include some measures of drug abuse seems imperative because much criminal law enforcement in the US over the last decades has been dedicated to the "war on drugs." About a quarter of US prisoners serve time for drug possession or trafficking. ${ }^{12}$

\footnotetext{
${ }^{10}$ The ICVS supplies survey weights that neutralize over- or undersampling within countries.

${ }^{11}$ I do not include sexual offenses against women in this count because this question was not asked in all surveys, and in any event would presumably yield answers that are not necessarily comparable across countries.

${ }^{12}$ Cf. Bureau of Justice Statistics, Prisoners in 2012, NCJ 243920 (December 2013), table 3 (reporting that the most serious offense of $23 \%$ of state prisoners in 1991 and $16.6 \%$ in 2011 was a drug of-
} 
When drug-related crimes such as dealer warfare are included, the number is presumably much higher.

To be sure, drug-related deaths are only the tip of the iceberg, and surely the "war on drugs" is also concerned with less dramatic drug abuse. Moreover, the GBD measure does not distinguish abuse of illegal drugs and prescription drugs such as opioids. I therefore also use data on drug use prevalence for opiates, cocaine, and ecstasy from the UN's World Drug Report 2012 (UNODC 2012a). These data derive mainly from questionnaire answers submitted by UNODC member states for years between 2000 and 2011; they should be interpreted with caution (UNODC 2012b).

\subsubsection{Punishment: Incarceration Rate}

For punishment data, I focus on the incarceration rate per 100,000 inhabitants compiled by the International Center for Prison Studies (ICPS) in its first nine World Prison Reports (e.g., Walmsley 2012). These data are very reliably measured (cf. Neapolitan 2001; LappiSeppälä 2008) and offer nearly universal country coverage. Their only shortcoming is that they are not available before the mid-1990s. For the later examination of time trends, I therefore also use UNODC data going back to 1970 but with much smaller country coverage. The correlation of the UNODC and ICPS log-transformed measures is 0.93 .

To my knowledge, there are no other reliable data on punishment - prison conditions, probation, parole, etc. - available for larger samples. There is data on the application of the death penalty, but it offers little cross-country variation as only a quarter of the world's countries retain the death penalty and only ten percent carry it out. In any event, the US is such a clear outlier on this dimension that considering the death penalty would only reinforce this paper's conclusions. ${ }^{13}$

\subsection{Independent variables}

As independent variables, I attempt to use all of the main variables suggested in the comparative literature on crime and punishment, provided they are exogenous and available for the large cross-section. ${ }^{14}$ In particular, and subject to the aforementioned proviso, I use all of the

fense), and http://www.bop.gov/about/statistics/statistics_inmate_offenses.jsp (visited 6/12/2014) (reporting that $50 \%$ of federal prisoners [approximately $15 \%$ of the total inmate population] were serving time for drug offenses).

${ }^{13}$ The US is the only Western country, one of very few developed countries, and one of only 58 countries worldwide to retain the death penalty; it is one of only 21 countries to have carried out an execution in 2012 (Amnesty International 2013).

${ }^{14}$ Independent variables that have been used in the comparative literature but are almost certainly simultaneously determined with crime and (official) punishment are extrajudicial killings (Neapolitan 2001), and crime and official punishment themselves. Dills et al. (2008) regress crime on a large set of criminal justice variables, arguing that the coefficients provide important information in spite of the endogeneity concerns. 
variables suggested in the cross-country regression literature on crime ${ }^{15}$ and punishment ${ }^{16}$, or close substitutes thereof. The twenty independent variables thus selected fall into four broad categories:

1. Development: $\log$ and level of GDP per capita, PPP-adjusted;

2. Institutions: legal origin (common law, socialist, or other), federalism, democracy, proportional voting, and freedom;

3. Demographics: the population share of main religious groups (Protestant, Catholic, Muslim, or other), descendants of former slaves, immigrants, urban population, and men aged 15-19; ethnic fractionalization; and the share of teen births among all births;

4. Social: Gini coefficient, employment protection (as a proxy for social policies), and the unemployment rate.

The appendix describes data sources and briefly summarizes the voluminous literature motivating the variables.

Perhaps the most conspicuous omission in the list above is gun ownership. The reason for the omission is that gun ownership is not plausibly exogenous. Increased crime might lead citizens to arm themselves in defense. I will return to the gun issue in the discussion part. While some other variables, particularly in the fourth group, might also be affected by crime, any such effect is likely to be small.

Not all of the variables listed above are likely to have an equally strong direct effect on both crime and the severity of punishment (sentence length and probability of apprehension). There are three reasons, however, why I nevertheless use all of them for predicting both crime and punishment (incarceration). First, the incarceration rate is not a pure measure of the severity of punishment, but its product with the crime rate. Second, the core of the economic model of crime is that the severity of punishment and the crime rate are simultaneously determined, so that any variable structurally influencing one of them will at least predict the other as well. Third, as shown in the appendix, almost all of the independent variables plausibly have at least some direct structural influence on both crime and the severity of punishment, or are correlated with an unobserved variable that does.

\section{Regression specifications: missing data}

The basic cross-sectional regression setup is straightforward. (I explain the construction of the residual time series in section 4.3 below.) I regress the outcome variable on a US

\footnotetext{
${ }^{15}$ Messner et al. (2002); Fajnzylber et al. (2002); Soares (2004); Hunt (2006); Lin (2007).

${ }^{16}$ Neapolitan (2001); Jacobs and Kleban (2003); Ruddell (2005); Anckar (2006); Downes and Hansen (2006); Greenberg and West (2008).
} 
dummy and a set of controls. I log-transform the dependent variables because it facilitates the residuals' use for elasticity calculations (see infra section 5) and, more generally, because the effects of the independent variables are most plausibly multiplicative, not additive; it also reduces the weight of outliers. The US dummy thus captures the log difference between the actual US rate and the rate predicted by the model. The robust standard error on the US dummy is exactly the prediction error one would obtain if one were to run the regression without the US and predict the US value from US covariates. ${ }^{17}$ The US data do not influence the prediction itself (i.e., the estimation of the rest of the model) because they are absorbed by the dummy. ${ }^{18}$

There are, however, a number of subtleties relating to dealing with limited degrees of freedom. This is a major problem in comparative analyses because the number of countries is at best around 200, and many of them do not provide data, at least not in the same year.

\subsection{Interpolation}

First, I linearly interpolate data on several variables to fill in missing values. This should introduce only minor measurement error as these variables are slow-moving. It is standard in international data (Durlauf et al. 2005). In fact, some data, such as the ILO unemployment data, are explicitly provided in interpolated form from the outset.

I interpolate data on incarceration (as the ICPS does, too); religion, urbanization, and migration, which are only provided at five-year intervals; freedom (which has one gap year in 1981 due to changing measurement periods); and on the share of teen births, which have fewer and irregular gaps. In the case of the Gini coefficient for use in the main crosssectional estimates, I also extrapolate from earlier or later measurements, and interpolate from a separate data series; details are in the appendix.

\subsection{Pooling}

Second, I pool observations on the dependent variables from different years. This concerns the ICVS and the drug use data, which have been collected in different countries in different years. To account for possible changes in data collection methods and global crime trends, I include dummies for the sweep or year, respectively.

In the case of the ICVS, I also include a dummy for the survey type (national or city). Furthermore, to give each country equal weight, I weight each country by the inverse of the number of years for which it has data. I cluster standard errors at the country level.

\footnotetext{
${ }^{17}$ By contrast, the classical (homoskedastic) standard error on the dummy would be equal to the standard error of the forecast. I have verified that the robust standard errors are otherwise appropriate, i.e., not meaningfully different and generally larger than the classical standard errors.

${ }^{18}$ If there is more than one US observation in the multi-year sample, US variation over time will affect the other estimated coefficients. This is relevant only in table 3 .
} 


\subsection{Statistical techniques: multiple imputation, etc.}

Third and most importantly, I use three different statistical techniques to address remaining missing data on the independent variables. While all three have limitations, they should collectively give some confidence that the results are robust.

\subsubsection{MI and FIML}

The most standard method in statistics, and the only one I use for the ICVS and drug data, is multiple imputation (MI). For each dependent variable, I impute 200 samples using chained linear regression equations and bootstrapped samples; I do not impute the dependent variable (i.e., I restrict the sample to observations with data on the respective dependent variable). For the homicide and incarceration rates, I also show largely identical results from full-information maximum likelihood (FIML).

To make their assumptions credible, MI and FIML require dropping a very small number of observations. First, MI and FIML assume that the data are missing at random (MAR) conditional on the non-missing data (Little and Rubin 2002). The main reasons for missing data are presumably poverty and undemocratic governments who conceal data. I therefore drop the few observations that miss data on GDP or indicators for democracy and freedom. Second, MI and FIML technically rely on multivariate normal distributions. They typically handle deviations from this assumption better than the alternatives (Graham 2009). Nevertheless, to avoid the most severe complications from non-normality, I exclude a very small number of observations for which categorical variables (legal origin and democracy) are missing.

\subsubsection{Missing dummies (OLS+)}

Another technique I use with the homicide and incarceration data, again with very similar results, is to introduce a set of dummies indicating missing status for each variable that has missing data, and to fill in the missing data itself with zeroes. This slightly changes the interpretation of the coefficients on the original variables. In particular, the coefficients are now estimates of the slope for those observations that have data, which might differ from the population. The advantage, however, is that with this modified interpretation, the technique can accommodate arbitrary patterns of missing data.

\section{Results}

The models generally perform well, as measured by $R^{2}$ and joint tests of the predictors. In particular, they predict a good part of the high US crime rates. However, they only predict one fifth of the US incarceration rate. Figure 4 (the residual counterpart to figure 
1) captures this key result. It shows that the US remains an extreme outlier with respect to incarceration even after partialling out covariates, and even while the residual homicide rate remains positive.

The results are robust to various perturbations. Over time, the US has gone from having mainly a large unexplained crime (homicide) rate to having mainly a large unexplained incarceration rate.

\subsection{Basic results}

Tables 1 through 3 show the basic cross-sectional results for the homicide rate (IHME, 2005) and the incarceration rate (ICPS, 2005), various victimization rates (ICVS, 1989-2005), and the drug related death rate (IHME, 2005) and drug use rates (UNODC, 2000-2011), respectively. The US results are quite insensitive to the method used for dealing with missing data, including the naive method of using only complete observations. The basic picture that emerges is that the puzzle persists even after partialling out the covariates. Residual US crime rates are either positive or statistically indistinguishable from zero, while the residual US incarceration rate is positive and very large, both economically and statistically. The actual US incarceration rate is four times higher than the predicted rate, and even the lower $95 \%$ confidence bound is 2.5 times.

The point estimates for the residual crime rate differ by type of crime. The residual homicide rate is about 0.6 points on the $\log$ scale, or $85 \%$. That is, actual US homicide rates are $85 \%$ higher than predicted by the model. The residual overall victimization crime rate is about -0.04 points on the $\log$ scale, or $4 \%$ below the prediction. This estimate is quite noisy, however, with a standard error of 0.19. For component victimization rates, the estimates are even noisier, reflecting the larger sampling error (cf. section 2.1.1 above). While the point estimates for residual US victimization rates from car theft, theft, robbery, and assault are negative, the residual rate for burglary is positive. Estimates for drug crimes are similarly noisy and mixed. The estimates for the most serious drug crimes or rather manifestations thereof, drug-related deaths and opiate use, are positive, however, and even statistically significant at the $10 \%$ level.

While the puzzle thus persists in the residuals, it is worth pointing out that it is smaller than in the raw data. This is true even for the US incarceration rate: it exceeds the prediction by a factor of five, but it exceeds that of many conventional peer countries (i.e., Western OECD countries) by at least as much and up to a factor of ten. Similarly, the US homicide rate exceeds the prediction by a factor of almost two, but it exceeds that of its conventional peers by a factor of three to ten. Finally, the US overall victimization rate is on the high end among its conventional peers, but actually slightly below the prediction, i.e., the synthetic comparison country. 
The main variables that predict high US homicide rates relative to other OECD countries are the high teen birth rate, high income inequality, lax labor laws, high ethnic fractionalization, and young (male) population. The products of the multiple-imputation estimated coefficients for these variables and the difference of their US values and the OECD means are $.33, .17, .12, .11$, and .11 , respectively, suggesting they collectively account for $.84 \log$ points, or $130 \%$, additional homicides in the US relative to the OECD mean. The variables that predict an elevated US incarceration rate are the high teen birth rate and the absence of proportional democracy, which respectively add .38 and .19 to the US prediction relative to the OECD mean. For the most part, these coefficients are also relatively precisely estimated, suggesting that these are not mere fluke findings.

\subsection{Model fit and robustness}

While the models cannot well explain the US incarceration rate, they generally perform very well. The $R^{2}$ in the OLS specifications of table 2 is very high (0.62 in model 2 , and 0.53 in model 6). Comparable specifications with the victimization rate yielded an $R^{2}$ of 0.5 (not shown). For MI and FIML, $R^{2}$ is not a meaningful measure. But the joint $p$-value for the regressors from an $F$-test is less than 0.0005 in most models and less than 0.01 in all but the model for common theft $(p=0.22)$. At least as a group, the regressors, motivated through work on much smaller samples, thus pass their out-of-sample test.

As already mentioned, nothing hinges on the method for dealing with missing data. In addition to the results shown, I have also run all the tests using "naive" model selection. I ran regressions first with small, related blocks of explanatory variables, and second with all those that had a $t$-statistic of at least 1.64 in the first set. In either case, the results for the US were qualitatively the same.

I have also investigated if a more complex functional form could explain the US position better, and found that it could not, at least in as much as the data allow such a test. To do so, I first generate up to third order polynomial interactions of all variables, using separate dummies for all possible combinations of binary variables. I then use the LASSO to select a (small) set of predictors for the dependent variables (the incarceration and homicide rates, respectively) and, in principle, the US dummy (here no predictor is selected). In a second step, I regress the dependent variables on the US dummy and the selected predictors. Belloni et al. (2012) have shown that this "Post-LASSO" method yields valid standard errors (only) for the "treatment" on the assumption that the correct model is approximately sparse (i.e., it contains only few regressors, even if their identity is initially unknown). In the present context, the "treatment" is the US effect. Its estimate using the Post-LASSO on the complete data is .96 and 1.68 for the log homicide and incarceration rates, respectively, with standard errors of .76 and .53. How, if at all, the Post-LASSO could be used with multiply imputed 
data is an open question. Using only a single set of imputed data, I obtained point estimates (standard errors) of $.83(.84)$ and $1.12(.64)$, respectively. ${ }^{19}$

\subsection{Trends over time}

The US outlier characteristic is also robust over time, event though its shape changes.

To establish a baseline, figure 5 shows time series of the raw data. Panel 1 shows levels of the US incarceration, homicide, and victimization rates for all years available. ${ }^{20}$ Panel 2 shows those same rates in logs net of the constant-sample world mean, and smoothed using lowess. Two features stand out. First, the US had comparatively high homicide and incarceration rates for as far back as we have data (the 1950s and 1970s, respectively). The US was always at least half a log point above the annual constant-sample world average. This is worth emphasizing because it is often said that US incarceration rates were hovering around 100 per 100,000 population in the early 1970s, comparable to other countries. This estimate seems based on a narrow and misleading focus on the imprisonment rate, however, as the rate including jails stood at around 200 even in the 1960s (other countries do not distinguish jails and prisons). Only the US victimization rate has been not far above and recently at the world mean. Second, US incarceration rates steadily increased since the early 1970s, while US crime rates came down, if not always steadily or in exact synchronization (cf. McCrary and Sanga 2011).

Figure 6 shows that the residual US incarceration rate steadily rose from just above zero in the 1970s to its current high level. The near-zero residual in the 1970s is noteworthy because, as just shown, the raw US incarceration rate was far above the world mean even back then. During that same time period since the 1970s, US residual homicide rates possibly came down from even higher levels, but unsteadily and, depending on the estimate, perhaps not significantly. The details depend on the method for estimating the residual time trend.

Panel 1 of figure 6 shows annual US dummy coefficients and 95\% confidence intervals from straightforward panel extensions of the main cross-sectional estimates for homicides, incarceration, and overall victimization. For victimization, the only change to model 1 of

\footnotetext{
${ }^{19}$ These standard errors are biased downwards because they do not account for the imputation variance (Rubin and Little 2002).

${ }^{20}$ The data are from the US Bureau of Justice Statistics, the FBI's Uniform Crime Reports, and the ICVS, respectively. Reliable victimization data are unavailable for earlier periods. The National Crime Victimization Survey was fundamentally redesigned in 1992 and older data are not currently available from the Bureau of Justice Statistics, cf. http://www.bjs.gov/developer/ncvs/index.cfm and http://www.bjs.gov/index.cfm?ty=pbdetail\&iid=2173\#section (both visited 4/27/2014). Other data series, in particular the Uniform Crime Reports, are not reliable for earlier years, cf. the comparison of trends of victimization data against crimes reported to law enforcement in US Department of Justice, Office of Justice Programs, Office of Victims of Crime, 2013 National Crime Victims' Rights Week Resource Guide, section 6, pp. 4-7, available at http://www.victimsofcrime.org/docs/ncvrw2013/2013ncvrw_stats_crimetrends.pdf?sfvrsn=0 (visited 4/27/2014), and cf. Vollaard and Hamed (2012) for similar problems with British data.
} 
table 2 is that the MI regression now contains a separate US dummy for each year (sweep). The homicide and incarceration regressions underlying the first panel are identical to models 2 and 6 of table 1, respectively, except that the regressions now use all country-year observations for which there is data on the dependent variable, year dummies (homicide) or a quadratic time trend (incarceration), and of course separate US dummies for each year with US data. Standard errors are clustered at the country level. The clear disadvantage of the first panel's approach is that the main comparative data series do not go far back in time.

Panel 2 instead combines domestic US data with the cross-country coefficient estimates. That is, it multiplies annual US domestic data for the independent variables by the MI coefficient estimates from models 3 and 7 of table 1 to derive the predicted annual US homicide and incarceration rates. It then shows the difference between these predictions and the actual US rates, along with $95 \%$ confidence intervals. This approach takes advantage of the fact that US domestic data are available for many more years than the comparative data series. The disadvantage of this approach is that it must assume constancy of the model over many decades. This is problematic because crime decreased throughout the developed world during that time period (van Dijk and Tseloni 2012).

Panel 3 allows at least a quadratic time trend (i.e., changing intercepts), at the cost of using poorer data and dropping some covariates altogether. It shows annual US dummy coefficients and 95\% confidence intervals from regressions of WHO homicide and UNODC incarceration rates on a quadratic trend and all but three of the independent variables of tables 1-3. The regressions also contain missing value dummies, as models 2 and 6 of table 1. The three independent variables that are missing are labor laws, unemployment, and the teen birth rate. Historical data for these variables are not available or at least extremely scarce before the 1990s. Given the teen birth rate's contribution to explaining high US crime rates, its omission may be responsible for at least some of the high US homicide residual in panel 3 .

\section{Joint Bounds}

The upshot is that the variables suggested in the literature only partially explain the US crime puzzle sketched in the introduction. While they explain a large part of the crosscountry variance and predict some of the high US crime rates, they grossly underpredict the US incarceration rate. In the past, the US residual crime rate may have been higher and the US residual incarceration rate lower. But the US has been an outlier for as long as we have data. The puzzle thus remains. Either US residual punishment is not working in the aggregate, contrary to most micro evidence on incapacitation and deterrence effects. Or US latent crime is unusually high, above and beyond what the cross-country models predict, and high residual punishment just offsets this. 
In this section, I derive joint bounds on these two possible explanations, accounting for estimation error. I initially make the simplifying assumption that the elasticity $\eta$ of the crime rate $C$ with respect to expected punishment per crime $\Pi$ is constant, both within and across countries. $^{21}$ Any use of LATE estimates for society-wide policy analysis implicitly makes the first assumption, and any use of foreign estimates the second. It is not an unreasonable assumption; in particular, it is compatible with (strongly) diminishing returns to punishment (as in the Italian data of Buonanno and Raphael 2013). In any event, the simplified model will serve as a useful benchmark for the subsequent discussion of more general models.

\subsection{Notation}

The only functional form consistent with the constant elasticity assumption is $C=K \Pi^{\eta}$, where $K$ is the country-specific latent crime rate. Mechanically, the overall steady-state rate of punishment (incarceration) is then $P=\Pi C=K \Pi^{1+\eta}$.

Denote the natural logarithms of $P, C, K$ and $\Pi$ by $p, c, k$, and $\pi$, their linear predictions by $p^{*}, c^{*}, k^{*}$, and $\pi^{*}$, and the difference between the two (i.e., the prediction error, or residual rate etc.) by $\varepsilon_{p}, \varepsilon_{c}, \varepsilon_{k}$, and $\varepsilon_{\pi}$, respectively. By definition and $C=K \Pi^{\eta}$,

$$
\begin{aligned}
& c^{*}=k+\eta \pi-\varepsilon_{c} \\
& p^{*}=k+(1+\eta) \pi-\varepsilon_{p},
\end{aligned}
$$

where the residual crime and incarceration rates can be decomposed as

$$
\begin{aligned}
\varepsilon_{c} & =\varepsilon_{k}+\eta \varepsilon_{\pi} \\
\varepsilon_{p} & =\varepsilon_{k}+(1+\eta) \varepsilon_{\pi}
\end{aligned}
$$

The US dummy coefficients in this paper's regressions are estimates $\hat{\varepsilon}_{p}^{U S A}, \hat{\varepsilon}_{c}^{U S A}$ of $\varepsilon_{p}^{U S A}$, $\varepsilon_{c}^{U S A}$. They are subject to finite sample estimation error, measured by the dummies' standard errors.

\section{$5.2 \quad$ Estimates}

The precise estimates depend on the measure of $C$, i.e., the type of crime used in the estimation. To provide upper and lower bounds, I focus on the lowest and the highest

\footnotetext{
${ }^{21}$ This elasticity is not the same as the elasticity of crime with respect to the prisoner population mentioned in the introduction. Denoting the latter by $\zeta$, the two are related as $\zeta=\frac{\eta}{1+\eta}$.
} 
among the more reliably (MI) estimated residual US crime rates, namely those for overall victimization from smaller crimes $(-0.04)$ and homicides (0.62).

The victimization residual would imply $\hat{\varepsilon}_{\pi}^{U S A}=\hat{\varepsilon}_{p}^{U S A}-\hat{\varepsilon}_{c}^{U S A}=1.41$, while the homicide residual would imply $\hat{\varepsilon}_{\pi}^{U S A}=0.75 .^{22}$ The comparative macro data thus suggest that expected prison sentences in the US are between two and four times longer than predicted, i.e., than in the synthetic comparison country. This accords with anecdotal evidence (e.g., Tonry 2001; Blumstein et al. 2005). On top of it, the anecdotal evidence suggests that US prison conditions are harsher as well.

The puzzle then is why the US residual crime rate is not commensurately negative. For $\varepsilon_{c}=\varepsilon_{k}+\eta \varepsilon_{\pi}$ to hold when $\varepsilon_{\pi}>>0$ and $\varepsilon_{c} \approx 0$, it must be that either $\eta \approx 0$ or $\varepsilon_{k}>0$, or both. To be more precise, for any given $\eta$, we have $\varepsilon_{k}=\varepsilon_{c}-\eta\left(\varepsilon_{p}-\varepsilon_{c}\right)$. Figure 7 graphs this relationship using this paper's estimates $\hat{\varepsilon}_{c}^{U S A}$ and $\hat{\varepsilon}_{p}^{U S A}$, along with $95 \%$ confidence bounds for the estimation error. ${ }^{23}$ The left panel uses $\hat{\varepsilon}_{c}^{U S A}$ from the overall victimization rate for smaller crimes, while the right panel uses $\hat{\varepsilon}_{c}^{U S A}$ from the homicide rate.

As the right panel shows, $\eta<0$ would imply a large $\varepsilon_{k}^{U S A}$ even at the lower $95 \%$ confidence bound of estimation error if homicides were a good proxy for overall crime. But even when proxying " $C$ " with the overall victimization rate, many elasticities estimated in the literature could be constant across countries only if residual US latent crime were very large. For example, $\eta=-0.74$ from deterrence alone (Drago et al. 2009) would imply a lower $95 \%$ confidence bound for $\varepsilon_{k}^{U S A}$ of 0.68 . Even when using the victimization rate residual, the point estimate for $\varepsilon_{k}^{U S A}$ is zero only if $\eta=0$.

To be sure, the $95 \%$ confidence bound for $\varepsilon_{k}^{U S A}$ derived using the victimization rate (barely) includes zero if $\eta=-0.25$, as suggested in a literature summary by Abrams (2013:961n219). One might therefore believe that any appearance of a puzzle for smaller crimes is merely an artefact of estimation error. Importantly, however, this would leave intact the puzzle for other types of crime, specifically homicides and serious drug crimes.

\footnotetext{
${ }^{22}$ The lower $95 \%$ confidence bound for $\varepsilon_{\pi}$ is 0.32 even using the homicide estimates, and the $99.9 \%$ confidence interval excludes zero regardless of which crime rate one considers. These and all other reported confidence intervals use a $t$-distribution, small sample corrections for the standard errors, and, where applicable, country clustering for the standard errors.

${ }^{23}$ The US homicide residual and estimation error were derived with MI for 2005 in the countries where both incarceration and homicide data are available $(N=170)$. The US victimization rate residual and estimation error were not obtained with MI because victimization data are not available for most countries, let alone country-years, with incarceration data, while the imputation model should include both dependent variables. Instead, the estimates underlying the left panel derive from regressions with dummies indicating missing values, and use all incarceration data for 2005 and the latest ICVS measure available for each country, if any. The US point estimates in these regressions are very similar to tables 1 and 2 . In both cases, robust standard errors and $t$-statistics are adjusted for small samples.
} 


\subsection{Relaxing assumptions}

\subsubsection{Crime-specific incarceration rates and elasticities}

Ideally, one would perform entirely separate analyses for different types of crimes. This would require data on punishment by crime type, however, which are not available for large samples.

As a first approximation, it seems reasonable to assume that US residual incarceration rates and, more to the point, punishment per crime are uniformly high across crime categories. Accounts of US "punitiveness" do not distinguish different sorts of crime (e.g., Whitman 2003). This is true even at the top end of the scale. Other countries have abolished the death penalty, and the US practice of imposing life without parole is virtually unheard of elsewhere, even for mass killings (Lerner 2013). ${ }^{24}$ In this case, the analysis from the previous subsection applies directly.

If US punishment were particularly heavy for some crimes, then the puzzle for those crimes would be larger, while the puzzle for other crimes would be smaller. If one also believed that elasticities are larger for some crimes than others, then differentiated US punitiveness could deepen or resolve the puzzle. The former (latter) would occur if the US punished high elasticity crimes relatively more (less) harshly. Empirically, there is very mixed evidence for differentiated elasticities. While Johnson and Raphael (2013) find that the crime-prison elasticity is higher for property crimes than for violent crimes, Levitt (1996) and Buonanno et al. (2011) find the opposite.

\subsubsection{Diminishing elasticity}

The elasticity might also vary with the level of punishment. In particular, punishment might exhibit more than proportionally diminishing returns. This would explain why elasticities estimated on foreign data (Drago et al. 2009; Buonanno et al. 2011; Buonanno and Raphael 2013; Barbarino and Mastrobuoni 2014) tend to be much higher than elasticities that most researchers have found in the US (e.g., Helland and Tabarrok (2007); McCrary and Lee 2009; Abrams 2012; Johnson and Raphael 2013). It would also explain why within the US, Johnson and Raphael (2013) find a higher elasticity in 1978-1990 than in 1991-2004.

As a first take, accounting for a diminishing elasticity would only deepen the US crime puzzle. As shown, zero residual latent US crime rates are barely compatible with modest crime-punishment elasticities around -0.25 on the assumption that those elasticities are constant (and even then only for smaller crimes). If elasticities were actually larger in

\footnotetext{
${ }^{24}$ For example, Anders Breivik received only 21 years in Norwegian prison for killing 76 people. In the United States, he would almost certainly have been sentenced to life in far less pleasant prison conditions, and quite possibly have been executed (Mary Slattery, Why is Breivik Facing a Maximum Sentence of Just 21 Years?, New Republic 8/1/2011).
} 
absolute value at lower levels of punishment, then the "average" elasticity would be larger as well, and the US crime rate should be concomitantly lower.

One would get closer to solving the puzzle if one believed the near-zero deterrence elasticity point estimates of Lee and McCrary (2009) were in fact representative of the US situation today, even though crime might be very responsive to punishment at lower levels of incarceration. ${ }^{25}$ In essence, this would be the argument that "mass incarceration does not work," which I will take up in the discussion to follow.

\section{Discussion}

To summarize the preceding section, an explanation of this paper's point estimates requires a combination of a near-zero crime-punishment elasticity and an account why latent US homicides and serious drug crimes are about $75 \%$ above the comparative prediction. Even allowing for sizeable estimation error by moving to the $95 \%$ confidence bound, any nonpositive elasticity implies a sizeable residual for latent homicides and serious drug crimes, and elasticities below -0.27 would require a positive residual for smaller crimes as well. I will discuss first the plausibility of low elasticities, and then that of high residual latent crime rates.

\subsection{Ineffective US punishment}

The hypothesis that the marginal benefit of incarceration is low or even zero at current US levels is closely related to the weaker hypothesis that it may not be worth the cost (e.g., Cook and Ludwig 2011; Abrams 2013).

At the micro level, the logic of deterrence and incapacitation might suggest that (the threat of) additional incarceration must work. Incapacitation benefits decrease strongly as convicts age, however, and thus as sentences get longer. As to deterrence, it is blunted by criminals' (beta-)discounting (Lee and McCrary 2009) and perhaps lack of information (Hjalmarsson 2009). As mentioned, Lee and McCrary (2009) do indeed estimate a deterrence elasticity near zero.

Moreover, even if marginal punishment worked at the micro level, it might be counterproductive at the macro level (see, e.g., Western 2006; McCrary and Sanga 2012; National Research Council 2014). Mass incarceration may disrupt communities (Clear 2008), and it may remove the stigma effect of incarceration. It has collateral, possibly criminogenic effects on prisoners' children (Murray and Farrington 2008). Inmates may return with even less human and more criminal capital and connections than before, sharply increasing recidivism

\footnotetext{
${ }^{25}$ Other low estimates of the crime-punishment elasticity from deterrence include Helland and Tabarrok (2007) (from whose estimates Lee and McCrary [2009, p. 6] calculate an elasticity of -0.07) and Abrams (2012) (finding an elasticity of -0.10).
} 
rates relative to milder sanctions such as monitoring (e.g., di Tella and Schargrodsky 2013; Aizer and Doyle 2013). The former effects are difficult to test in cleanly identified designs, but they may be extremely important.

There may also be specific features of how US punishment is administered that reduce its effectiveness, in particular by increasing recidivism rates. In the US but not in other countries, criminal records are publicly accessible, hindering reintegration (Western 2006). Nominal sentences in the US are much longer than the time convicts actually serve, arguably diminishing their effectiveness through a framing effect (Bushway and Owens 2013). And again, prison conditions in the US are tough.

An especially important factor might be sentence length. It tends to be very high in the US, even while other countries may have higher prison admission rates (Young and Brown 1993). Because of discounting, longer sentences generate less deterrence for a given level of expected punishment (Durlauf and Nagin 2011). There is also good evidence suggesting that the long US sentences hardly reduce post-release recidivism (e.g., Ganong 2012). That being said, at least by some accounts, the increase in the US incarceration rate has been driven by higher prison entrance rates, not longer sentences (Langan 2005; Pfaff 2011; but see National Research Council 2014).

Institutionally, the very features that arguably make the US punish more harshly may also make the US punish in a less targeted manner. For example, Berdejo and Yuchtman (2013) show that elected judges punish more harshly before elections, implying at the very least suboptimal variance in sentencing. Elections for judges and prosecutors are virtually unique to the US. Similarly, many of the populist political dynamics that have arguably led to increased and perhaps less targeted punishment in the US (e.g., Jacobs and Jackson 2010) have been absent in Western Europe (e.g., Hammel 2010). In and of itself, however, US punitiveness is not an explanation for why the punitive regime does not lead to reduced crime. For example, the US war on drugs may explain why the US incarcerates so many people for drug crimes. ${ }^{26}$ But it does not explain why hard drug abuse and drug related deaths are then still higher than predicted in the US.

\subsection{High US latent crime rates}

The hypothesis of a high US residual latent crime rate is amorphous by definition. The residual reflects any factor omitted as an independent variable, including mismeasurement and functional misspecification (to the extent not addressed by the post-LASSO method).

Many other outlier countries in figure 4 have rather obvious country-specific explanations. For example, Rwanda has the largest residual incarceration rate in 2005 because it still imprisoned a large number of accused and convicted participants of the 1994 genocide

\footnotetext{
${ }^{26}$ See supra p. 6. In any event, other countries incarcerate drug offenders too.
} 
(Walmsley 2012). Conversely, the Congo had the lowest residual incarceration rate presumably because its dysfunctional state institutions do not sustain a functioning court and prison system. If Congo's residual homicide rate is nevertheless zero, this is presumably because extrajudicial punishment takes the place of incarceration, or because the situation is so bad that even homicides are undetected.

The US does not have similarly obvious special circumstances. To be sure, the list of factors with a potential influence on crime is long, including for example school hours and lead paint (e.g., Kleiman 2009). At the same time, most of those factors could not plausibly generate the large residual latent crime required to explain the data, at least on their own. They either do not seem important enough (school hours), or they are unlikely to differ much between developed countries (lead paint). For example, policing is demonstrably very important (e.g., di Tella and Schargrodsky 2004; DeAngelo and Hansen 2014; cf. Levitt 2004), but there is no indication that US policing is particularly bad.

I thus discuss only three omitted factors that could plausibly have a large effect and differ substantially between countries: deinstitutionalization, guns, and segregation.

\subsubsection{Deinstitutionalization}

In the second half of the 20th century, the number of mentally ill people in mental hospitals declined precipitously in the US. At the same time, the rate of mentally ill people in jails and prisons is now very high. Nevertheless, Raphael and Stoll (2013) estimate that only 4 to $7 \%$ of the growth of the US prison population in the 1980-2000 and none before can be explained by "transinstitutionalization." This could at most explain a tiny fraction of the excess US residual incarceration rate.

\subsubsection{Guns}

In the US, firearms are notoriously easy to procure, and most US murders are committed with a gun (Donohue 2013). The regressions did not control for this. This was intentional; gun ownership is endogenous if and because citizens acquire guns to protect themselves from crime.

In unreported robustness checks, however, I did include a control for the number of firearms per population (from the Small Arms Survey (Karp 2007)) in the dummy regressions for incarceration and violent crime (homicide, robbery, and assault). ${ }^{27}$ This only made the US residual larger in all but the robbery regression. To be sure, the introduction of an

\footnotetext{
${ }^{27}$ I also used an additional dependent variable, gun homicides in 2005 (from IHME 2013). Here, the other coefficient estimates do change considerably from the overall homicide regression. In particular, the US residual is considerably larger (1.87) than in the regressions with all homicides. Controlling for firearm ownership rates now reduces the US coefficient a little to 1.17 , but it remains above the US coefficient in the basic homicide regression.
} 
endogenous regressor might negatively affect the quality of the prediction. But the coefficients on the other regressors did not significantly change, suggesting that the endogeneity problem is not that important.

Substantively, the limited impact of the firearm regressor is driven by the fact that many Western European countries with very low homicide rates have very high gun ownership rates as well (e.g., Finland, France, Germany, Norway, Sweden, and Switzerland), while many countries with low gun or medium ownership rates, particularly in Africa and Latin America, have very high homicide rates. How many guns there are may not matter nearly as much as who has them.

The foregoing empirical analysis is subject to important caveats (cf. Donohue 2013). The available data do not distinguish between handguns and long guns, or the type of long guns. For crime, handguns and assault rifles are most problematic. The data also do not control for various ways of regulating gun ownership beyond mere numbers. In general, the data quality is low. The comparative data thus cannot rule out an important role for guns and gun regulation in explaining US crime and punishment. But they also do not provide support for it.

\subsubsection{Segregation}

The main regressions did include income inequality and ethnic fractionalization. Higher levels of these variables predict higher homicide rates, and higher inequality also predicts high other crime rates. The levels, however, hardly capture all the relevant variation. For example, the US and Singapore have similarly high levels of income inequality and ethnic fractionalization. But while Singapore forces integration in mostly government-built housing and publicly funded schools (OECD 2011), neighborhoods and schools in the US are highly segregated by income and ethnicity.

Many have emphasized the unequal distribution of crime and punishment in the US even within the same city (e.g., Sampson 2013; Sampson and Loeffler 2010). In cities like Chicago, crime and punishment are heavily concentrated in just a few overwhelmingly African American neighborhoods that are also suffering in other dimensions. To the extent such concentration is merely a regrouping of otherwise constant characteristics and behavior, it would not affect any averages and hence would not yield any new predictions. But if the concentration of crime and punishment is the result of negative dynamics in these neighborhoods, higher levels of de facto racial and social segregation (coupled with neighborhood dilapidation) in the US than elsewhere might increase latent US crime relative to other countries. There is some micro-econometric evidence for such dynamics (Damm and Dustmann 2014).

Comparative data on segregation are not available. One can at least check, however, if the US data are broadly consistent with the hypothesis, i.e., if crime and punishment are concentrated in areas with high levels of segregation. To test this, I use the data set of 
Chetty et al. (2014), who compile various measures of segregation and social capital at the commuting zone level. Since I am interested in punishment, which is at the state level, I collapse the data at that level. In unreported regressions, I find that homicide and incarceration are indeed strongly concentrated in states with high levels of social segregation, high fractions of African Americans, and low levels of social capital (which are highly correlated with one another). ${ }^{28}$

At the broadest level, this connection manifests in a simple scatter plot of incarceration and homicide rates by states, shown in figure $8 .{ }^{29}$ It shows that homicide and incarceration rates tend to be much higher in the South than in the rest of the US. At the same time, the plot also shows that there is something special about the United States as a whole. Even the New England states incarcerate a higher fraction of the population than any OECD country except Estonia, and their homicide rates rank on par with the highest ones observed in Western Europe.

\section{Conclusion}

This paper has shown that standard comparative theories of crime and punishment only partially explain the high crime and incarceration rates of the United States relative to other developed nations. Regressions estimated on the largest cross-country data set more or less predict US crime rates, but they predict only one fourth of the actual US incarceration rate. Either US residual punishment is not working well, or some omitted factor, such as segregation, pushes up US latent crime. Most plausibly, both are true.

In either case, the findings of this paper suggest an opportunity for researchers and policy makers to shift attention from punishment to other levers of crime control. Future research might investigate possible reasons why US mass incarceration may not work, or identify factors that push up US latent crime, or both. Such research holds the promise of making incarceration more effective, or replacing it with cheaper levers to control crime. ${ }^{30}$

\footnotetext{
${ }^{28}$ Relatedly, Kearney and Levine (2012) find that US teen birth rates are particularly high among minorities and in states with high income inequality.

${ }^{29}$ The homicide rates are averaged over the three years 2004-06 to avoid small sample noise in small states.

${ }^{30}$ See Cook and Ludwig (2011) for a discussion of the cost-effectiveness of various levers.
} 


\section{Appendix: Theory and Sources of Independent Variables}

This appendix describes the data sources for the independent variables, and briefly summarizes the voluminous literature motivating them. For reviews of this literature, see Neapolitan (1997), Whitman (2005), Tonry (2007), Lappi-Seppälä (2008), and Lynch and Pridemore (2011).

Development. All of the cited cross-country studies control for the level of development, usually operationalized as GDP per capita. ${ }^{31}$ In fact, the impact of development is so fundamental that presumably most other theories implicitly hold the level of development constant, and I control for it in all of the regressions. ${ }^{32}$ The level of development affects the opportunity set of potential criminals, and the institutional capacity of public law enforcement. More subtly, the level of development may also affect, or be affected by, social structures that informally suppress or encourage crime, and steer human behavior more generally. Finally, a "civilization" effect may lead to less severe punishment in more developed societies. To account for the possibility of the latter effect, I control for the level of development non-linearly in the homicide and incarceration regressions, using both the level of GDP per capita and its natural logarithm. PPP-adjusted data come from the Penn World Tables 7.1 (Heston et al. 2012).

Income inequality and social policy. At least since Ehrlich (1973), another major focus of the prior literature has been income inequality and the policies that influence it (e.g., Kelly 2000; Fajnzylber et al. 2002; Messner et al. 2002; Choe 2008; Dahlberg and Gustavsson 2008). The economic literature on crime mostly emphasizes the effect of income inequality on the opportunity set of potential criminals (e.g., Burdett et al. 2003; Foley 2011). In the criminological and sociological literature on punishment, income inequality is also viewed as a proxy for, and consequence of, social policies defining the relationship between the well-off and the less well-off, which are the major focus of that literature (e.g., Downes and Hansen 2006). Di Tella and Dubra (2008) generate similar coincidences in an economic model. In that view, societies that support the poor with generous welfare spending, and that support employees with protective labor regulation, are also likely to employ only moderate punishment. ${ }^{33}$ I control for income inequality using the Gini coefficient, and for labor regulation

\footnotetext{
${ }^{31}$ Some authors, such as Neapolitan (2001), use instead the Human Development Index, which combines GDP per capita, life expectancy, and educational achievement; I used it in some regressions with identical results. Other authors, such as Soares (2004), separately include the level of education. I found that coefficients on a variable of primary school enrollment or adult literacy have the same sign as those for GDP per capita (less crime, more punishment) without adding explanatory power or altering the results for other variables. Since I do not see a theoretical reason for adding this separate variable, and to conserve degrees of freedom, I do not report results with this variable.

${ }^{32}$ Soares (2004) provides a full review of the relevant empirical literature.

${ }^{33}$ For an economic model linking these features, see di Tella and Dubra (2008).
} 
using the World Bank's index of the ease of hiring and firing a worker for 2007 (World Bank 2007). ${ }^{34}$

I obtain Gini data preferably from the OECD Income Distribution database, and otherwise from the World Bank's World Development Indicators (WDI). Both measure post-tax, post-transfer (i.e., disposable) income inequality, which fits the above theories. ${ }^{35}$ Some WDI Gini data go back to 1978, but they become quite sparse long before that, and many countries only have a measure for one year, usually in the late 1990s. To deal with this, I first linearly interpolate data for missing years. I then predict missing values from a regression of the interpolated OECD/WDI data on a Gini measure constructed from pay data by the University of Texas Inequality Project (UTIP) (Galbraith and Kim 2005) (I use only the UTIP measure in panel 3 of figure 6). Finally, in the cross-sectional tests, I fill in remaining missing values with the latest or earliest measurement available. This seems appropriate because income inequality is quite stable over time. Its year-to-year autocorrelation is 0.97 , and the within-country standard deviation (3.5) is only $37 \%$ of the between-country standard deviation (9.5).

Political structure. In the aforementioned criminological literature, differences in social policy are usually viewed in a broader context of different political systems. This literature tends to include in the analysis classifications such as corporatism (Jacobs and Kleban 2003), social democracies vs. neoliberal systems vs. conservative corporatist systems (e.g., Cavadino and Dignan 2006a/b), or consensus vs. conflict political systems (Lappi-Seppälä 2008). Since these classifications are only available for relatively small groups of countries, however, I instead use proportional voting, which is often viewed as conducive to, or even a hallmark of, social democracies or consensus systems.

I construct the measure of proportional voting from the World Bank's Database of Political Institutions (Beck et al. 2001) using the formula of Pagano and Volpin (2005). ${ }^{36}$ Since proportional voting only matters in democracies, I also include a democracy dummy, and "switch on" the proportional voting variable only when the dummy is equal to one. To the extent possible, I fill missing data with hand-collected data from Wikipedia.

In fact, Lin (2007) and others have suggested that democracies punish minor crimes less harshly and hence have more of it, and inversely for major crime. Like Lin, I use the Fraser Institute's political rights and civil liberties scores (Gwartney et al. 2012) to control for democracies and liberty more broadly, adding the two subscores and rescaling them so that

\footnotetext{
${ }^{34}$ The index was discontinued, and is not available in the World Bank's electronic databases.

${ }^{35}$ The WDI data descriptions do not say so explicitly. But they are almost perfectly correlated with the OECD post tax and transfer measures, much less so with the pre tax and transfer measures. They are also very closely correlated with post tax/transfer measures from the World Income Inequality Database of the World Institute for Development Research (WIDER).

${ }^{36}$ Concretely, I use DPI 2012 revised January 2013. The formula is (PR - PLURALTY - HOUSESYS + 2)/3.
} 
higher values correspond to more freedom. ${ }^{37}$ I interpolate data for one gap year (1981).

Finally, Jacobs and Kleban (2003) have argued that federal systems should have more prisoners because relevant political decisions will be less remote from the population and hence more subject to populist pressures for harsh punishment. I control for (constitutionally guaranteed) federalism using a dummy variable supplied by Tom Ginsburg of the Comparative Constitutions Project (Elkins et al. 2014). ${ }^{38}$

Population structure. The last major complex of variables considered in the literature is the structure of the population. It is well known that young males are particularly prone to criminal activity (Hirschi and Gottfredson 1983), and many cross-country studies attempt to control for this. I do so using the share of 15-19 year old males in the population, as reported by the US Census International Data Base.

Hunt (2006) has drawn attention to the associations of crime with young adults born to teen mothers, particularly when they reach age $25-29$. The US teen birth rate is exceptionally high among developed nations (Kearney and Levine 2012). I control for this using the share of children born to teen mothers out of all children born 25 years prior to the relevant year, calculated from the United Nations Demographic Yearbook Historic Supplement 1948-1997. (An alternative interpretation this variable is as a proxy for broader social dysfunctions, since it is highly correlated with the current share of teen births (calculated from the same sources).)

Many papers also control for the level of urbanization since crime tends to be more prevalent in cities (Glaeser and Sacerdote 1999). I do so using the population share living in urban areas in the relevant year (WDI).

Another important aspect of population structure considered in the literature is its homogeneity or heterogeneity (e.g., Ruddell 2005). Group differences might breed conflict and hence crime, and a government dominated by one group might have less reservations about punishing members of the other group. Relatedly, outsiders such as immigrants might be more inclinded to engage in crime for lack of alternatives or because of lower informal social control. ${ }^{39}$ To control for this, I use the index of ethnic fractionalization from Alesina et al. (2003), and the percentage of foreign born inhabitants (WDI).

More specifically, many observers view the experience of slavery and its legacy of charged race relationships as a major factor of US crime and crime policy (Western 2006; Tonry and Melewski 2008). In an attempt to account for this, I construct a measure of slavery legacy in non-African countries as the percentage of the population descendant from former African

\footnotetext{
${ }^{37}$ Lin (2007) uses the political rights score (and the civil liberties score as an instrument for it).

${ }^{38}$ The variable was constructed from a prior version of the database and takes value 1 if the constitution explicitly labels the country federal or confederal, or if it grants residual or superior lawmaking powers to subnational levels.

${ }^{39}$ Most empirical evidence does not support this conjecture, or only to a very limited extent, see, e.g., Bianchi et al. (2012); Chalfin (2014); Spenkuch (2014).
} 
slave exporter countries. I obtain measures of ancestry from Putterman and Weil (2009), and a list of African slave exporting countries from Nunn (2008) (counting only those that exported at least 250,000 slaves, for fear that I might otherwise end up counting non-slave migration).

Legal system. The legal system is obviously of the utmost importance for crime and punishment, as it determines the government-administered part of the latter. Comparative data on legal aspects of punishment are not available for large groups of countries, and in any event they would hardly be exogenous. There is evidence suggesting, however, that the historic origin of a legal system may play a role in punishment. Greenberg and West (2008), using the classification of Mukherjee and Reichel (1999), report that common law countries are significantly more likely than others (except Islamic law countries) to retain the death penalty. ${ }^{40}$

This ties into an important literature in economics that has documented pervasive correlations between "legal origins," i.e., common and civil law, and economic regulation and outcomes in areas ranging from investor protection to conscription (La Porta et al. 2008). While this literature has not specifically considered criminal law, it has found that common law countries tend to have more severe criminal sanctions, at least "on the books," for breaches of securities (La Porta et al. 2006) and corporate law (Djankov et al. 2008). Moreover, in a recent survey, La Porta et al. (2008:286) characterize "legal origin as a style of social control of economic life (and maybe other aspects of life as well)." Criminal law enforcement, however, is the archetype of social control in modern societies. "Social control" is broader, however, and may affect latent crime $(K)$ through other channels as well.

For continuity with the economics literature, I employ the legal origin classification from La Porta et al. (1999), maintaining socialist legal origin as a separate category to capture the special position of the transition economies with respect to crime and crime policy (cf. Neapolitan 2001; Lappi-Seppälä 2008). I added twelve jurisdictions for which data was missing from Klerman et al. (2011). ${ }^{41}$

Culture and religion. Some contributions place great emphasis on cultural factors. For example, Lappi-Seppälä (2008) argues that higher levels of trust are associated with less harsh punishment practices. Unfortunately, good measures of culture are notoriously

\footnotetext{
${ }^{40}$ Ruddell (2005) finds that common and civil law systems have, on average, higher incarceration rates than communist, mixed, and Islamic systems. His coefficient for common law systems is larger than for civil law systems, but he does not report tests of statistical significance of this difference. Related to legal origin, Jacobs and Kleban (2003) find higher incarceration rates in English-speaking countries, and Anckar (2006) finds that use of the death penalty in former colonies differs by the last colonizing power.

${ }^{41}$ The added jurisdictions are Congo-Brazzaville, French Guiana, French Polynesia, and Timor-Leste (French); the Channel Islands, British Virgin Islands, Palau, and Gibraltar (Common Law); East and West Germany prior to reunification (socialist and German, respectively); and Serbia, Montenegro, and Kosovo (socialist).
} 
difficult to obtain, and those that exist are available only for medium sample sizes. Moreover, some measures, such as the World Value Survey measures of trust in other people and the government used by Lappi-Seppälä (2008), are likely to be simultaneously determined with crime and punishment, as more crime presumably reduces trust in other people and the government (cf. Blanco and Ruiz 2013). I therefore do not report any results with culture variables.

I do, however, report results with a closely related set of variables available for large samples, namely religion. Whitman (2005:27-8) notes that studies of the role of religion in punishment "cry out to be done." For example, religion could reduce latent crime through informal social control, or modulate criminal law enforcement according to notions of mercy or retribution. Anckar (2006) and Greenberg and West (2008) find that higher percentages of Buddhist and perhaps Muslim inhabitants are associated with a higher likelihood of retaining the death penalty, while Catholics may be associated with a lower likelihood. Given the low number of countries with sizeable groups of Buddhists, I am skeptical about the possibility of disentangling their influence on the death penalty in a cross-country regression. I focus on the main world religions, employing measures of the percentage of the population identified as Muslim, Catholic, or Protestant, respectively, from the Association of Religion Data Archives' World Religions Dataset (Maoz and Henderson 2013).

Other independent variables. Many other variables have been discussed in the theoretical literature. Only two of them, however, have found application in many empirical studies, namely the unemployment rate (e.g., Altindag 2012), and the economic growth rate. I do not use the latter because of its frequent fluctuations, which make it seem unlikely that differential growth rates could explain much of the huge cross-country differences in crime and punishment. I do use total unemployment rates estimated by the International Labor Organization (WDI). A caveat here is that from the perspective of some criminological theories that argue for its importance, the unemployment rate is endogenous, because those theories argue that criminal punishment is used to control excess labour. 


\section{References}

1. Abadie, Alberto, Alexis Diamond, and Jens Hainmueller. 2010. Synthetic Control Methods for Comparative Case Studies: Estimating the Effect of California's Tobacco Control Program. Journal of the American Statistical Association 105:493-505.

2. Abrams, David S. 2012. Estimating the Deterrent Effect of Incarceration Using Sentencing Enhancements. American Economic Journal: Applied Economics 4:32-56.

3. 2013. The Imprisonner's Dilemma: A Cost-Benefit Approach to Incarceration. Iowa Law Review 98:905-969.

4. Aizer, Anna, and Joseph J. Doyle, Jr. 2013. Juvenile Incarceration, Human Capital and Future Crime: Evidence from Randomly-Assigned Judges. NBER Working Paper No. 19102.

5. Alesina, Alberto, Arnaud Devleeschauwer, William Easterly, Sergio Kurlat, and Romain Wacziarg. 2003. Fractionalization. Journal of Economic Growth 8:155-194.

6. Altindag, Duha T. 2012. Crime and unemployment: Evidence from Europe. International Review of Law and Economics 32:145-157.

7. Amnesty International. 2013. Death Sentences and Executions 2012. London: Amnesty International Publications.

8. Anckar, Carsten. 2006. Determinants of the Death Penalty - A comparative study of the world. London and New York: Routledge.

9. Barbarino, Alessandro, and Giovanni Mastrobuoni. 2014. The Incapacitation Effect of Incarceration: Evidence from Several Italian Collective Pardons. American Economic Journal: Economic Policy 6:1-37.

10. Beck, Thorsten, George Clarke, Alberto Groff, Philip Keefer, and Patrick Walsh. 2001. New Tools in Comparative Political Economy: The Database of Political Institutions. World Bank Economic Review 15:165-176.

11. Becker, Gary S. 1968. Crime and Punishment: An Economic Approach. Journal of Political Economy 76:169-217.

12. Belloni, Alexandre, Victor Chernozhukov, and Christian Hansen. 2012. Inference on Treatment Effects after Selection amongst High-Dimensional Controls. Working paper.

13. Berdejos, Carlos, and Noam Yuchtman. 2013. Crime, Punishment, and Politics: An Analysis of Political Cycles in Criminal Sentencing. Review of Economics and Statistics 95:741-756. 
14. Bianchi, Milo, Paolo Buonanno, and Paolo Pinotti. 2012. Do Immigrants Cause Crime? Journal of the European Economic Association 10:1318-1347.

15. Blanco, Luisa, and Isabel Ruiz. 2013. The Impact of Crime and Insecurity on Trust in Democracy and Institutions. American Economics Review: Papers 8 Proceedings 103:284-288.

16. Blumstein, Alfred, Michael Tonry, and Asheley van Ness. 2005. Cross-National Measures of Punitiveness. In Crime and Punishment in Western Countries, 1980-1999, ed. Michael Tonry and David P. Farrington, 347-376. Crime and Justice: A Review of Research 33. Chicago: University of Chicago Press.

17. Buonanno, Paolo, Francesco Drago, Roberto Galbiati and Giulio Zanella. 2011. Crime in Europe and the United States: dissecting the 'reversal of misfortunes.' Economic Policy 26:347-385.

18. Buonanno, Paolo, and Steven Raphael. 2013. Incarceration and Incapacitation: Evidence from the 2006 Italian Collective Pardon. American Economic Review 103:24372465 .

19. Burdett, Kenneth, Ricardo Lagos, and Randall Wright. 2003. Crime, Inequality, and Unemployment. American Economic Review 93:1764-1777.

20. Bushway, Shawn D., and Emily G. Owens. 2013. Framing Punishment: Incarceration, Recommended Sentences, and Recidivism. Journal of Law and Economics 56:301-331.

21. Cavadino, Michael, and James Dignan. 2006a. Penal Systems: A Comparative Approach. London, Thousand Oaks, and New Delhi: SAGE.

22. _ 2006b. Penal Policy and Political Economy. Criminology \& Criminal Justice 6:435-456.

23. Chalfin, Aaron. 2014. What is the Contribution of Mexican Immigration to U.S. Crime Rates? Evidence from Rainfall Shocks in Mexico. American Law and Economics Review 16:220-268.

24. Chetty, Raj, Nathaniel Hendren, Patrick Kline, and Emmanuel Saez. 2014. Where is the Land of Opportunity? The Geography of Intergenerational Mobility in the United States. Working Paper.

25. Choe, Jongmook. 2008. Income inequality and crime in the United States. Economics Letters 101:31-33. 
26. Clear, Todd R. 2008. The Effects of High Imprisonment Rates on Communities. Crime and Justice: A Review of Research 37:97-132.

27. Cook, Philip J., and Nataliya Khmilevska. 2005. Cross-National Patterns in Crime Rates. Crime and Justice: A Review of Research 33:331-345.

28. Cook, Philip J., and Jens Ludwig. 2011. Economical Crime Control. In Controlling Crime: Strategies and Tradeoffs, ed. Philip J. Cook, Jens Ludwig, and Justin McCrary, 1-42. Chicago: University of Chicago Press.

29. Dahlberg, Matz, and Magnus Gustavsson. 2008. Inequality and Crime: Separating the Effects of Permanent and Transitory Income. Oxford Bulletin of Economics and Statistics 70:129-153.

30. Damm, Anna Piil and Christian Dustmann. 2014. Does Growing Up in a High Crime Neighborhood Affect Youth Criminal Behavior? American Economic Review 104:1806-1832.

31. DeAngelo, Gregory, and Benjamin Hansen. 2014. Life and Death in the Fast Lane: Police Enforcement and Traffic Fatalities. American Economic Journal: Economic Policy 6:231-257.

32. Deininger, Klaus, and Lyn Squire. 1996. A New Data Set Measuring Income Inequality. World Bank Economic Review 10:565-591.

33. Di Tella, Rafael, and Juan Dubra. 2008. Crime and punishment in the "American Dream." Journal of Public Economics 92:1564-1584.

34. Di Tella, Rafael, and Ernesto Schargrodsky. 2004. Do Police Reduce Crime? Estimates Using the Allocation of Police Forces After a Terrorist Attack. American Economic Review 94:115-133.

35. 2013. Criminal Recidivism after Prison and Electronic Monitoring. Journal of Political Economy 121:28-73.

36. Dills, Angela K., Jeffrey A. Miron, and Garrett Summers. 2010. What do economists know about crime? In The Economics of Crime: Lessons for and from Latin America, ed. Rafael Di Tella and Ernesto Schargrodsky, 269-302. Chicago: University of Chicago Press.

37. Djankov, Simeon, Rafael La Porta, Florencio Lopez-de-Silanes, and Andrei Shleifer. The law and economics of self-dealing. Journal of Financial Economics 88:430-465. 
38. Donohue, John. 2013. Outlier Nation: Homicides, Incarceration, Guns and Gun Culture. Available at http://works.bepress.com/john_donohue/108.

39. Downes, David, and Kirstine Hansen. 2006. Welfare and Punishment in Comparative Perspective. In Perspectives on Punishment, ed. Sarah Armstrong and Lesley McAra, 133-154. Oxford: Oxford University Press.

40. Drago, Francesco, Roberto Galbiati, and Pietro Vertova. 2009. The Deterrent Effects of Prison: Evidence from a Natural Experiment. Journal of Political Economy 117:257280.

41. Durlauf, Steven N.. 2012. Comment. Cato Papers on Public Policy, 13:195-201.

42. __ Paul Johnson, and Jonathan Temple. 2005. Growth Econometrics. In Handbook of Economic Growth, ed. Philippe Aghion and Steven N. Durlauf, 1A:555677. Elsevier.

43. Durlauf, Steven N., and Daniel S. Nagin. 2011. Imprisonment and crime: Can both be reduced? Criminology \& Public Policy 10:13-54.

44. Ehrlich, Isaac. 1973. Participation in Illegitimate Activities: A Theoretical and Empirical Investigation. Journal of Political Economy 81:521-565.

45. Elkins, Zachary, Tom Ginsburg, and James Melton. 2014. Characteristics of National Constitutions, Version 2.0. Comparative Constitutions Project. Available at: http://www.comparativeconstitutionsproject.org.

46. Fajnzylber, Pablo, Daniel Lederman, and Norman Loayza. 2002. Inequality and Violent Crime. Journal of Law and Economics 45:1-40.

47. Foley, C. Fritz. 2011. Welfare Payments and Crime. Review of Economics and Statistics 93:97-112.

48. Galbraith, James K., and Hyunsub Kim. 2005. Estimating the Inequality of Household Incomes: A Statistical Approach to the Creation of a Dense and Consistent Global Data Set. Review of Income and Wealth 51:115-143.

49. Ganong, Peter N. 2012. Criminal Rehabilitation, Incapacitation, and Aging. American Law and Economics Review 14:391-424.

50. Gibson, John, and Bonggeun Kim. 2008. The effect of reporting errors on the crosscountry relationship between inequality and crime. Journal of Development Economics $87: 247-254$. 
51. Glaeser, Edward L., and Bruce Sacerdote. 1999. Why is there more crime in cities? Journal of Political Economy 107:S225-S258.

52. Graham, John. 2009. Missing Data Analysis: Making it Work in the Real World. Annual Review of Psychology 60:549-576.

53. Greenberg, David F., and Valerie West. 2008. Siting the Death Penalty Internationally. Law \& Social Inquiry 33:295-343.

54. Gwartney, James, Robert Lawson, and Joshua Hall. 2012. Economic Freedom of the World: 2012 Annual Report. Vancouver, B.C.: Fraser Institute.

55. Hammel, Andrew. 2010. Ending the Death Penalty: The European Experience in Global Perspective. Macmillan.

56. Helland, Eric, and Alexander Tabarrok. 2007. Does Three Strikes Deter? A Nonparametric Estimation. Journal of Human Resources 49:309-330.

57. Heston, Alan, Robert Summers and Bettina Aten. 2012. Penn World Table Version 7.1. Center for International Comparisons of Production, Income and Prices at the University of Pennsylvania.

58. Hirschi, Travis and Michael Gottfredson. 1983. Age and the Explanation of Crime. American Journal of Sociology 89:552-584.

59. Hjalmarsson, Randi. 2009. Crime and Expected Punishment: Changes in Perceptions at the Age of Criminal Majority. American Law and Economics Review 11:209-248.

60. Hunt, Jennifer. 2006. Do teen births keep American crime high? Journal of Law and Economics 49:533-566.

61. IHME. 2013. Global Burden of Disease Study 2010. Results by Cause 1990-2010 Country Level. Seattle: Institute for Health Metrics and Evaluation (IHME).

62. INTERPOL. 1999. International Crime Statistics for 1999. Saint Cloud: INTERPOL.

63. Jacobs, David, and Aubrey L. Jackson. On the Politics of Imprisonments: A Review of Systematic Findings. Annual Review of Law and Social Science 6:129-149.

64. Jacobs, David, and Richard Kleban. 2003. Political Institutions, Minorities, and Punishment: A Pooled Cross-National Analysis of Imprisonment Rates. Social Forces $82: 725-755$.

65. Johnson, Rucker, and Steven Raphael. 2012. How Much Crime Reduction Does the Marginal Prisoner Buy? Journal of Law and Economics 55:275-310. 
66. Karp, Aaron. 2007. Completing the Count: Civilian Firearms. In Small Arms Survey 2007, ed. Eric G. Berman, Keith Krause, Emile LeBrun, and Glenn McDonald. Cambridge, UK: Cambridge University Press.

67. Kearney, Melissa S., and Phillip B. Levine. 2012. Why is the Teen Birth Rate in the United States So High and Why Does It Matter? Journal of Economic Perspectives 26(2):141-166.

68. Kelly, Morgan. 2000. Inequality and Crime. Review of Economics and Statistics 82:530-539.

69. Kleiman, Mark. 2009. When Brute Force Fails: How to Have Less Crime and Less Punishment. Princeton: Princeton University Press.

70. Klerman, Daniel, Paul Mahoney, Holger Spamann, and Mark Weinstein. 2011. Legal Origin or Colonial History? Journal of Legal Analysis 3:379-409.

71. La Porta, Rafael, Florencio Lopez-de-Silanes, and Andrei Shleifer. 2006. What works in securities laws? Journal of Finance 61:1-32.

72. . 2008. The Economic Consequences of Legal Origins. Journal of Economic Literature 46:285-332.

73. , and Robert Vishny. 1999. The Quality of Government. Journal of Law, Economics, and Organization 15:222-279.

74. Langan, Patrick A. 2005. Crime and Punishment in the United States, 1981-1999. In Crime and Justice: A Review of Research 33, ed. Michael Tonry, 33-159. Chicago: University of Chicago Press

75. Lappi-Seppälä, Tapio. 2008. Trust, Welfare, and Political Culture: Explaining Differences in National Penal Policies. Crime and Justice: A Review of Research 37:313-387.

76. Lee, David S., and Justin McCrary. 2009. The Deterrence Effect of Prison: Dynamic Theory and Evidence. Working paper, UC Berkeley and Princeton.

77. Lerner, Craig. 2013. Life Without Parole as a Conflicted Punishment. Wake Forest Law Review 48:1101-1171.

78. Levitt, Steven D. 1996. The Effect of Prison Population Size on Crime Rates: Evidence from Prison Overcrowding Litigation. Quarterly Journal of Economics 111:319-351.

79. . 2004. Understanding Why Crime Fell in the 1990s: Four Factors that Explain the Decline and Six that Do Not. Journal of Economic Perspectives 18:163190. 
80. and Daniel Kessler. 1999. Using Sentence Enhancements to Distinguish between Deterrence and Incapacitation. Journal of Law and Economics 42:343-364.

81. Levitt, Steven D., and Thomas J. Miles. 2007. Empirical Study of Criminal Punishment. In Handbook of Law and Economics, ed. A. Mitchell Polinsky and Steven Shavell, 1:455-495. Amsterdam: North-Holland.

82. Lin, Ming-Jen. 2007. Does democracy increase crime? The evidence from international data. Journal of Comparative Economics 35:467-483.

83. Little, Roderick, and Donald Rubin. 2002. Statistical Analysis with Missing Data. 2nd ed. Hoboken, NJ: Wiley.

84. Lynch, James P. 2006. Problems and Promise of Victimization Surveys for CrossNational Research. In Crime and Justice: A Review of Research 34, ed. Michael Tonry, 229-287. Chicago: University of Chicago Press.

85. Lynch, James P., and William A. Pridemore. 2011. Crime in International Perspective. In Crime and Public Policy, ed. James Q. Wilson and Joan Petersilia, 5-52.

86. Maoz, Zeev, and Errol A. Henderson. 2013. The World Religion Dataset, 1945-2010: Logic, Estimates, and Trends. International Interactions 39:265-291.

87. McCrary, Justin, and Sarath Sanga. 2012. General Equilibrium Effects of Prison on Crime: Evidence from International Comparisons. Cato Papers on Public Policy, 13:165-193.

88. Messner, Steven F., Lawrence E. Raffalovich, and Peter Shrock. 2002. Reassessing the Cross-National Relationship between Income Inequality and Homicide Rates: Implications of Data Quality Control in the Measurement of Income Distribution. Journal of Quantitative Criminology 18:377-395.

89. Mukherjee, Satyanshu, and Philip Reichel. 1999. Bringing to Justice. In Global Report on Crime and Justice, ed. Graeme Newman, 65-88. New York and Oxford: Oxford University Press.

90. Murray, Joseph, and David P. Farrington. 2008. The Effects of Parental Imprisonment on Children. Crime and Justice: A Review of Research 37:133-206.

91. National Research Council. 2014. The Growth of Incarceration in the United States: Exploring Causes and Consequences, ed. Jeremy Travis, Bruce Western, and Steve Redburn. Washington, DC: National Academic Press. 
92. Neapolitan, Jerome L. 1997. Cross-National Crime: A Research Review and Sourcebook. Westport CT and London: Greenwood Press.

93. . 2001. An Examination of Cross-National Variation in Punitiveness. International Journal of Offender Therapy and Comparative Criminology 45:691-710.

94. Newman, Graeme, and Gregory J. Howard. 1999. Introduction: Data sources and their use. In Global Report on Crime and Justice, ed. Graeme Newman, 1-23. New York and Oxford: Oxford University Press.

95. Nunn, Nathan. 2008. The Long-Term Effects of Africa's Slave Trades. Quarterly Journal of Economics 123:139-176.

96. Pagano, Marco, and Paolo F. Volpin. 2005. The Political Economy of Corporate Governance. American Economic Review 95:1005-1030.

97. Pfaff, John F. 2011. The Myths and Realities of Correctional Severity: Evidence from the National Corrections Reporting Program on Sentencing Practices. American Law and Economics Review 13:491-531.

98. Putterman, Louis, and David N. Weil. 2009. Post-1500 Population Flows and the Long-Run Determinants of Economic Growth and Inequality. Quarterly Journal of Economics 125:1627-1682.

99. OECD. 2011. Lessons from PISA for the United States: Strong Performers and Successful Reformers in Education. Paris: OECD Publishing.

100. 2013. Crisis squeezes income and puts pressure on inequality and poverty: New Results from the OECD Income Distribution Database. Available at http://www. oecd.org/els/soc/OECD2013-Inequality-and-Poverty-8p.pdf (visited 7/2/2014).

101. Owens, Emily G. 2009. More Time, Less Crime? Estimating the Incapacitative Effect of Sentence Enhancements. Journal of Law and Economics 52:551-579.

102. Raphael, Steven, and Michael A. Stoll. 2013. Assessing the Contribution of the Deinstitutionalization of the Mentally Ill to Growth in the U.S. Incarceration Rate. Journal of Legal Studies 42:187-222.

103. Rodrik, Dani. 2009. The New Development Economics: We Shall Experiment, But How Shall We Learn? In What Works in Development? Thinking Big and Thinking Small, ed. Jessica Cohen \& William Easterly. Washington D.C.: Brookings.

104. Ruddell, Rick. 2005. Social Disruption, State Priorities, and Minority Threat. Punishment \& Society 7:7-28. 
105. Sampson, Robert J. 2013. The Place of Context: A Theory and Strategy for Criminology's Hard Problems. Criminology 51:1-31.

106. , and Charles Loeffler. 2010. Punishment's place: the local concentration of mass incarceration. Daedalus 20-31 (Summer).

107. Soares, Rodrigo R. 2004. Development, crime, and punishment: accounting for the international difference in crime rates. Journal of Development Economics 73:155-184.

108. Spenkuch, Jorg L. 2014. Understanding the Impact of Immigration on Crime. American Law and Economics Review 16:177-219.

109. Tonry, Michael. 2001. Prisons and Imprisonment. In The International Encyclopedia of the Social \& Behavioral Sciences, ed. Neil J. Smelser and Paul B. Baltes, 1206212067. Elsevier.

110. . 2007. Determinants of Penal Policies. In Crime, Punishment, and Politics in Comparative Perspective, ed. Michael Tonry, 1-48. Crime and Justice: A Review of Research 36. Chicago: University of Chicago Press.

111. , and David P. Farrington. 2005. Punishment and Crime across Space and Time. In Crime and Punishment in Western Countries, 1980-1999, ed. Michael Tonry and David P. Farrington, 1-39. Crime and Justice: A Review of Research 33. Chicago: University of Chicago Press.

112. , and Matthew Melewski. 2008. The Malign Effect of Drug and Crime Control Policies on Black Americans. Crime and Justice: A Review of Research 37:144.

113. UNODC (United Nations Office on Drugs and Crime). 2012a. World Drug Report 2012. New York: United Nations.

114. . 2012b. World Drug Report 2012. Statistical Annex: Methodology. Available at http://www.unodc.org/documents/data-and-analysis/WDR2012/Methodology.pdf.

115. van Dijk, Jan, John van Kesteren, and Paul Smit. 2007. Criminal Victimization in International Perspective: Key findings from the 2004-2005 ICVS and EU ICS. The Hague: WODC.

116. van Dijk, Jan, and Andromachi Tseloni. 2012. Global Overview: International Trends in Victimization and Recorded Crime. In The International Crime Drop, ed. Jan van Dijk, Andromachi Tseloni, and Graham Farrell, 133-154. New York: Palgrave Macmillan. 
117. van Kesteren, John. 2007. Integrated Database from the International Crime Victim Surveys (ICVS) 1989-2005, Data and Codebook. Tilburg: INTERVICT. Available at http://easy.dans.knaw.nl., database ID P1749.

118. Vollaard, Ben, and Joseph Hamed. 2012. Why the Police Have an Effect on Violent Crime After All: Evidence from the British Crime Survey. Journal of Law and Economics 55:901-924.

119. Walmsley, Roy. 2012. World Prison Population List, 9th ed. London: International Centre for Prison Studies.

120. Western, Bruce. 2006. Punishment and Inequality in America. Russell Sage Foundation: New York.

121. Whitman, James Q. 2003. Harsh Justice: Criminal Punishment and the Widening Divide between America and Europe. Oxford and New York: Oxford University Press.

122. . 2005. The Comparative Study of Criminal Punishment. Annual Review of Law and Social Science 1:17-34.

123. Wooldridge, Jeffrey M. Cluster-Sample Methods in Applied Econometrics. American Economic Review (papers \& proceedings) 93:133-138.

124. World Bank. 2007. Doing Business 2008. Washington DC: The World Bank and the International Finance Corporation.

125. Young, Warren, and Mark Brown. 1993. Cross-National Comparisons of Imprisonment. In Crime and Justice: A Review of Research, ed. Michael Tonry, 17:1-45. Chicago: University of Chicago Press. 
Figure 1: Homicide and incarceration

\section{Homicide and incarceration rates around the world \\ logs, 2005}

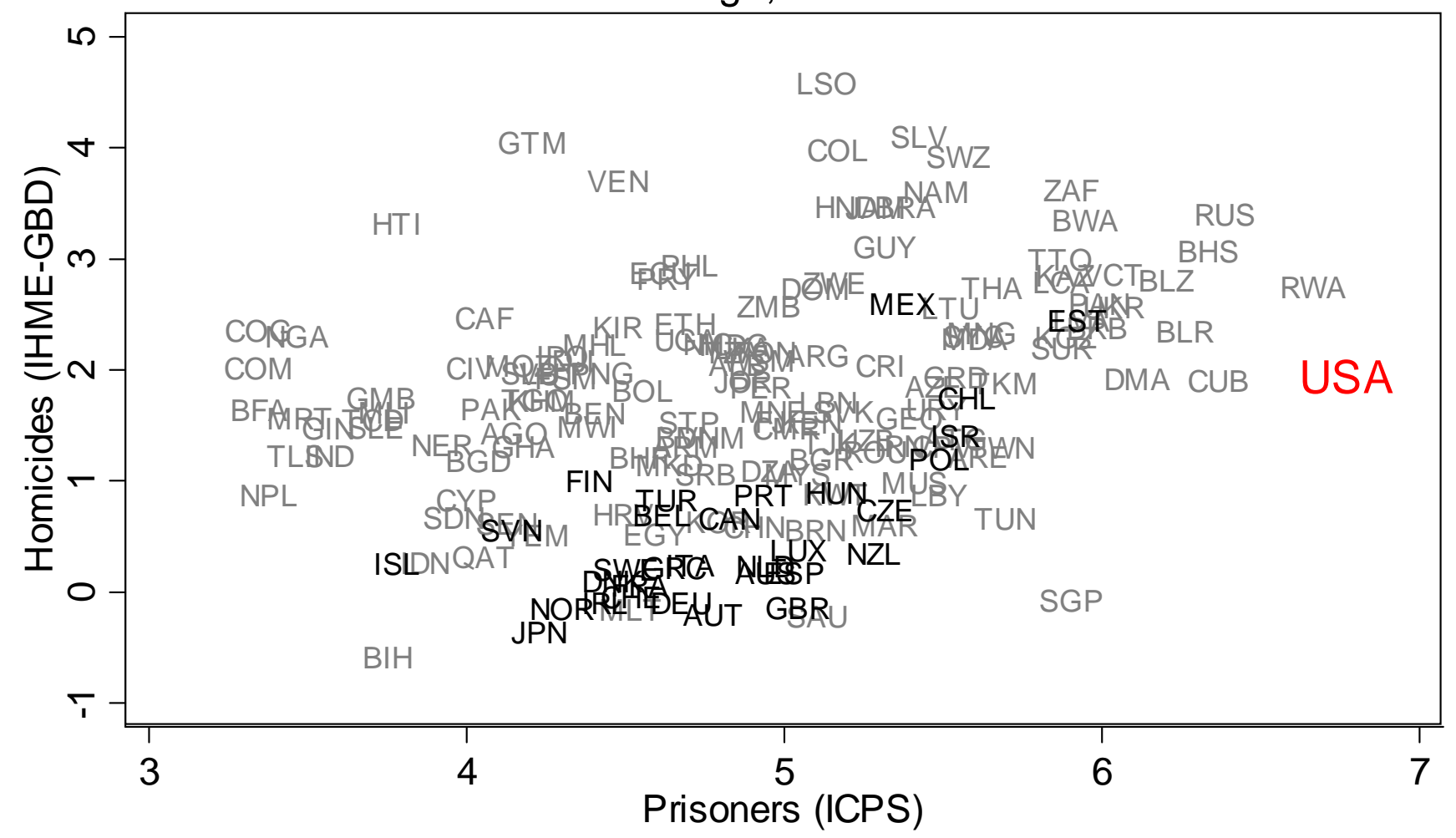

Countries included: union of estimation samples of models 2 and 6 of table 1 . OECD countries in solid black 
Figure 2: Distributions of dependent variables

\section{Dependent variables: distributions}
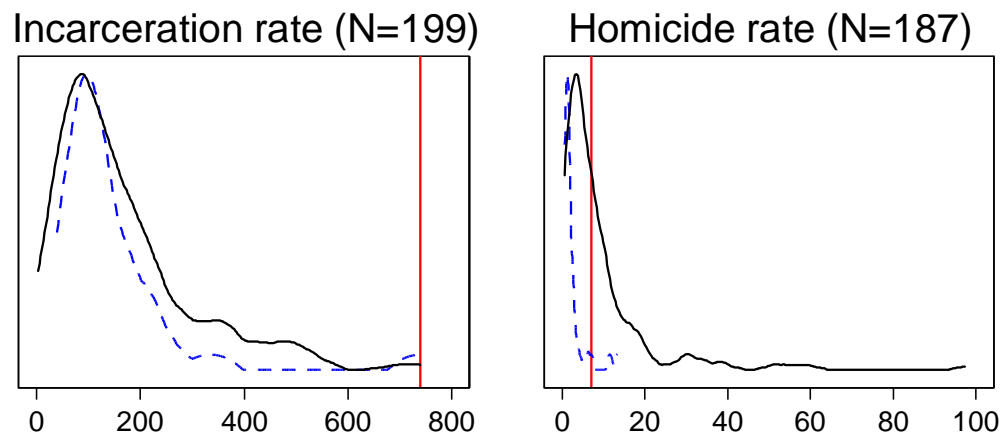

Drug death rate $(\mathrm{N}=187)$

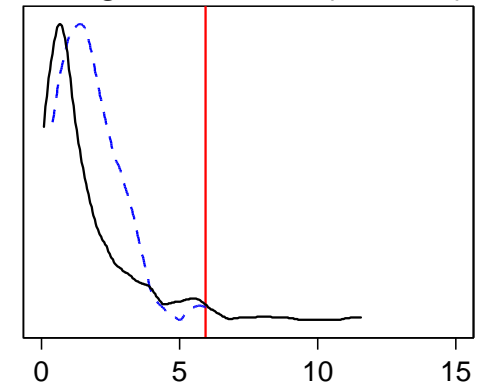

cocaine prevalence $(\mathrm{N}=99)$

ecstasy prevalence $(\mathrm{N}=101)$

opiates prevalence $(\mathrm{N}=103)$
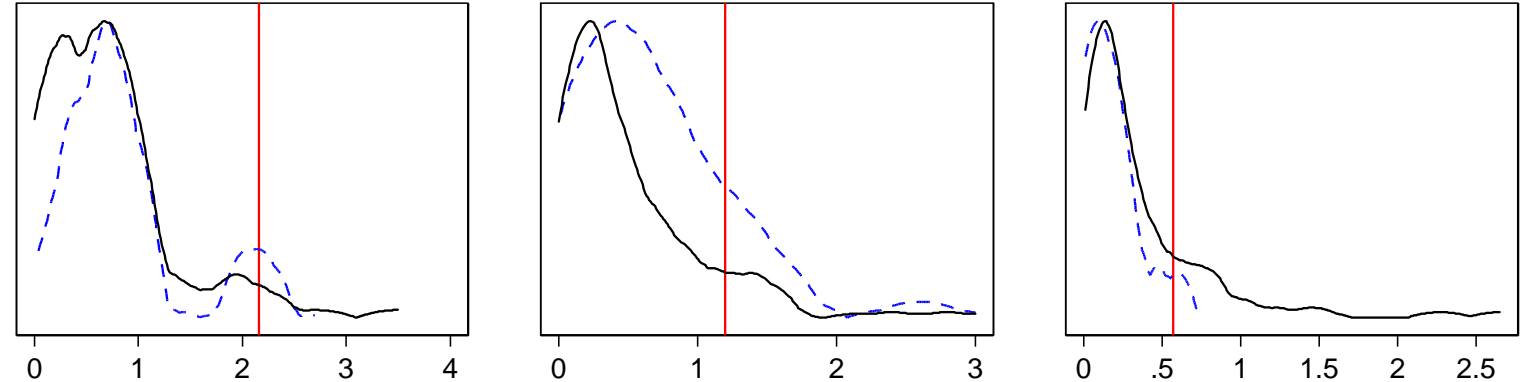

ICVS: Overall $(\mathrm{N}=73)$

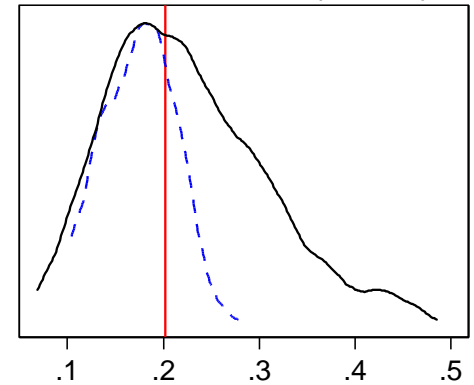

ICVS: Car theft $(\mathrm{N}=75)$

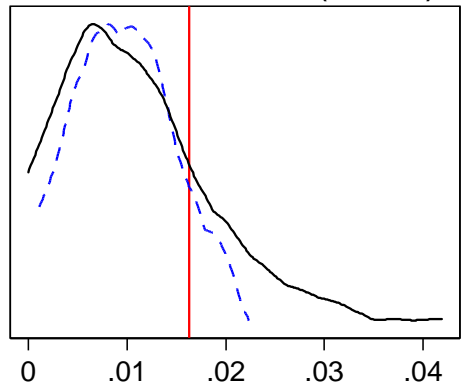

ICVS: Burglary $(\mathrm{N}=74)$

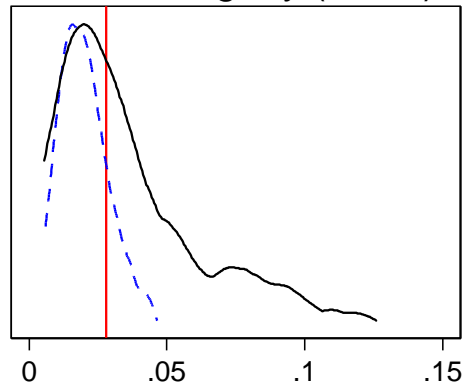

ICVS: Theft $(\mathrm{N}=75)$

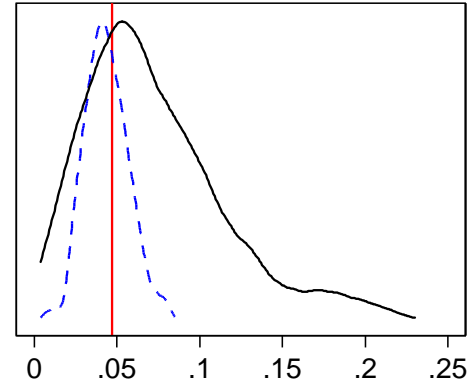

ICVS: Robbery $(\mathrm{N}=74)$

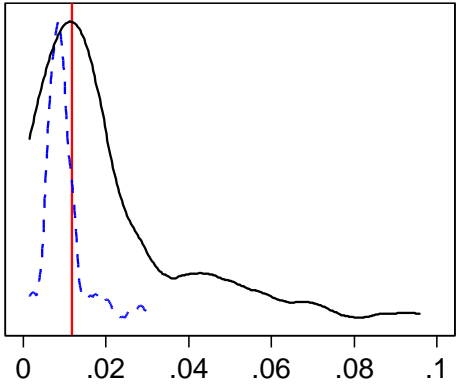

ICVS: Assault ( $\mathrm{N}=74)$

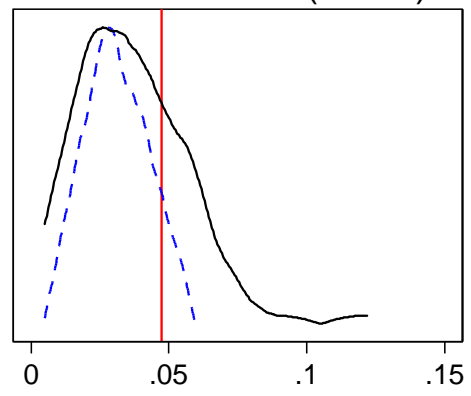

Incarceration, homicide, and drug death rates are annual rates per 100,000 measured in 2005.

Prevalence rates are annual rates per 100 measured between 2000 and 2011.

ICVS refers to the average victimization rate from the named crime, 1989-2005.

The vertical red line marks the US value.

Full kernel densities in solid black; OECD countries only in dashed blue.

Sources: see section 2.1. 
Figure 3: Distributions of independent variables

\section{Independent variables (2005): distributions}

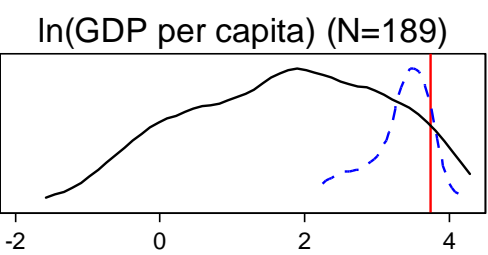

Federal state $(\mathrm{N}=197)$

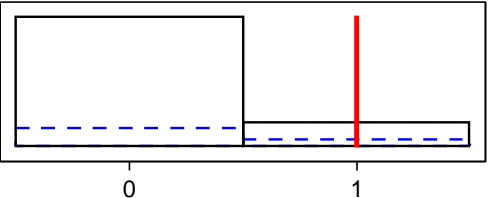

Freedom $(\mathrm{N}=194)$

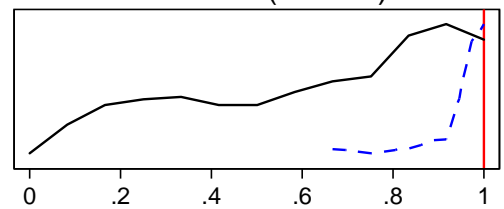

Muslim/pop. (N=199)

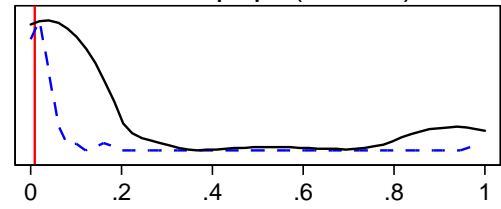

Immigrants/pop. ( $\mathrm{N}=209)$

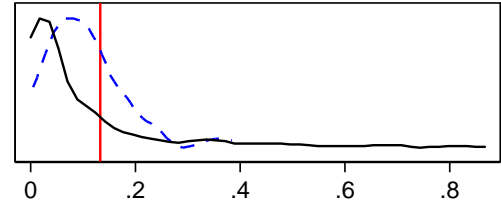

Teen/total births $(\mathrm{t}-25)(\mathrm{N}=108)$

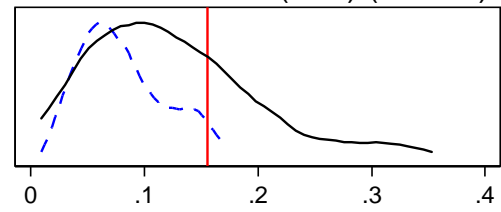

Unemployment rate $(\mathrm{N}=174)$

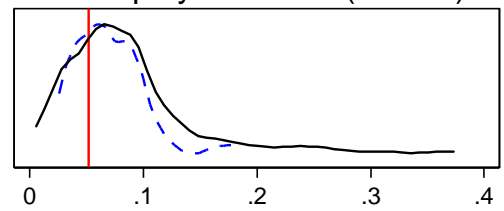

English legal origin $(\mathrm{N}=219)$

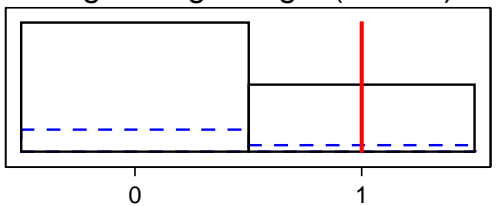

Democracy $(\mathrm{N}=214)$

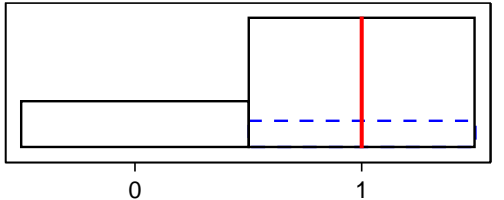

Protestant/pop. ( $\mathrm{N}=199)$

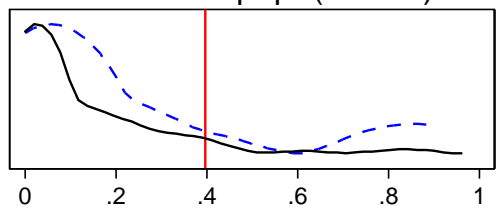

Slave descendants/pop. $(\mathrm{N}=165)$

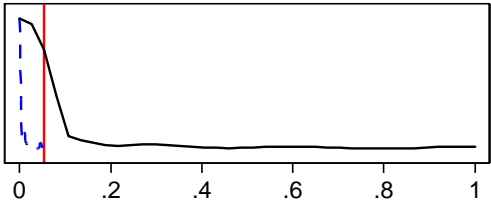

Ethnic fractionalization $(\mathrm{N}=190)$

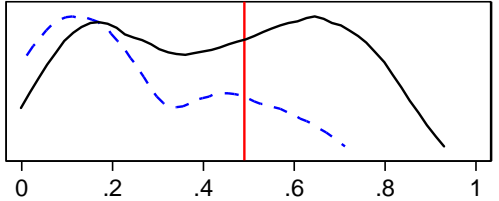

Males 15-19/pop. $(\mathrm{N}=224)$

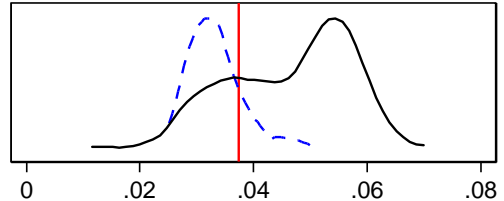

Difficulty firing worker ( $\mathrm{N}=133)$

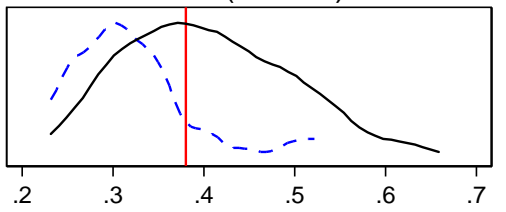

The vertical red line marks the US value.

Full distributions in solid black; OECD countries only in dashed blue.

The graphs show frequencies for binary variables and kernel densities for others.

Sources: see appendix. 
Figure 4: Residual homicide and incarceration

Residual homicide and incarceration rates around the world logs (2005)

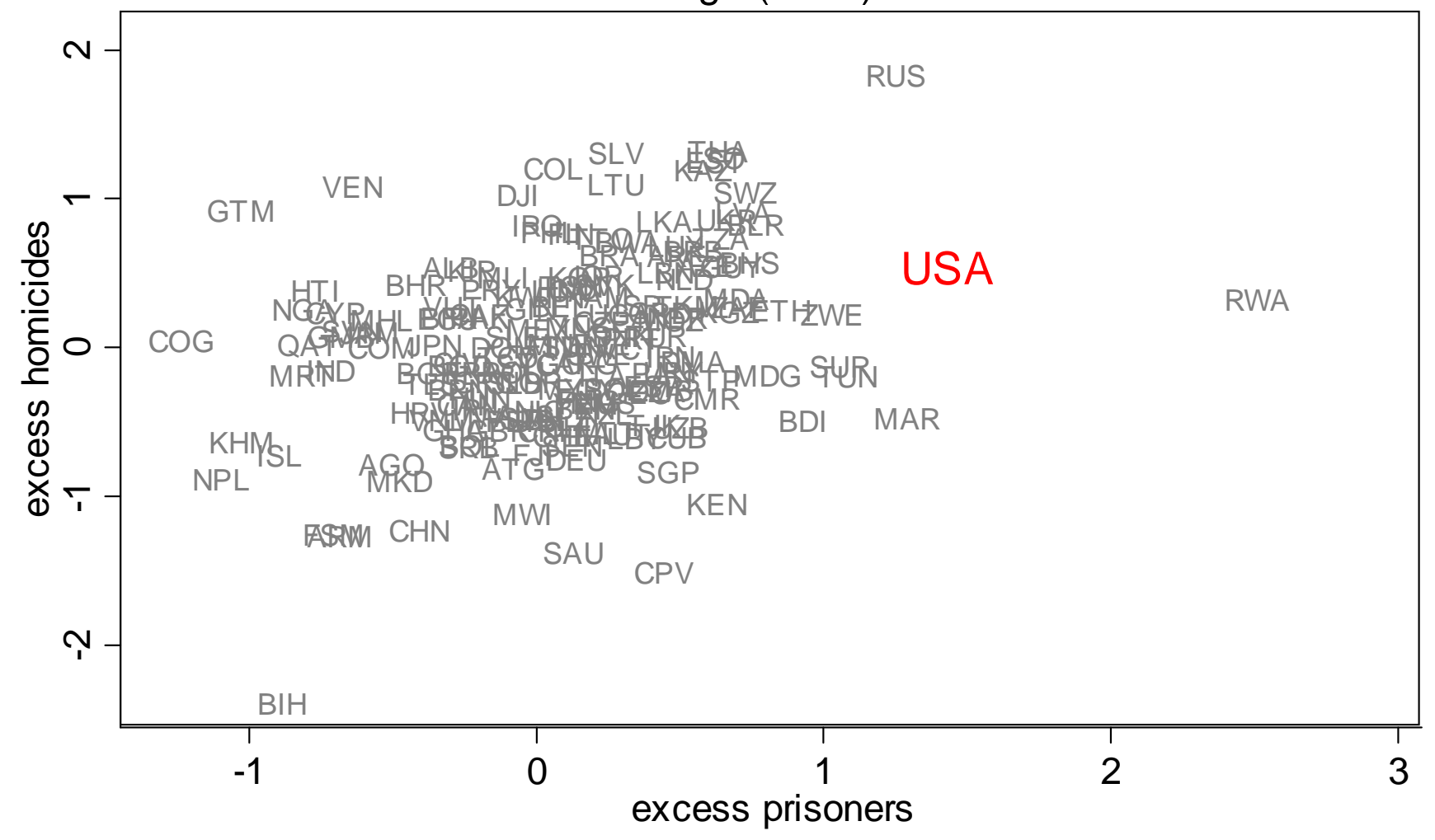

Residuals from models equivalent to models 2 and 6 of table 1 except that they do not contain a separate US dummy. 
Figure 5: Raw US crime and punishment over time

\section{US crime and punishment over time}

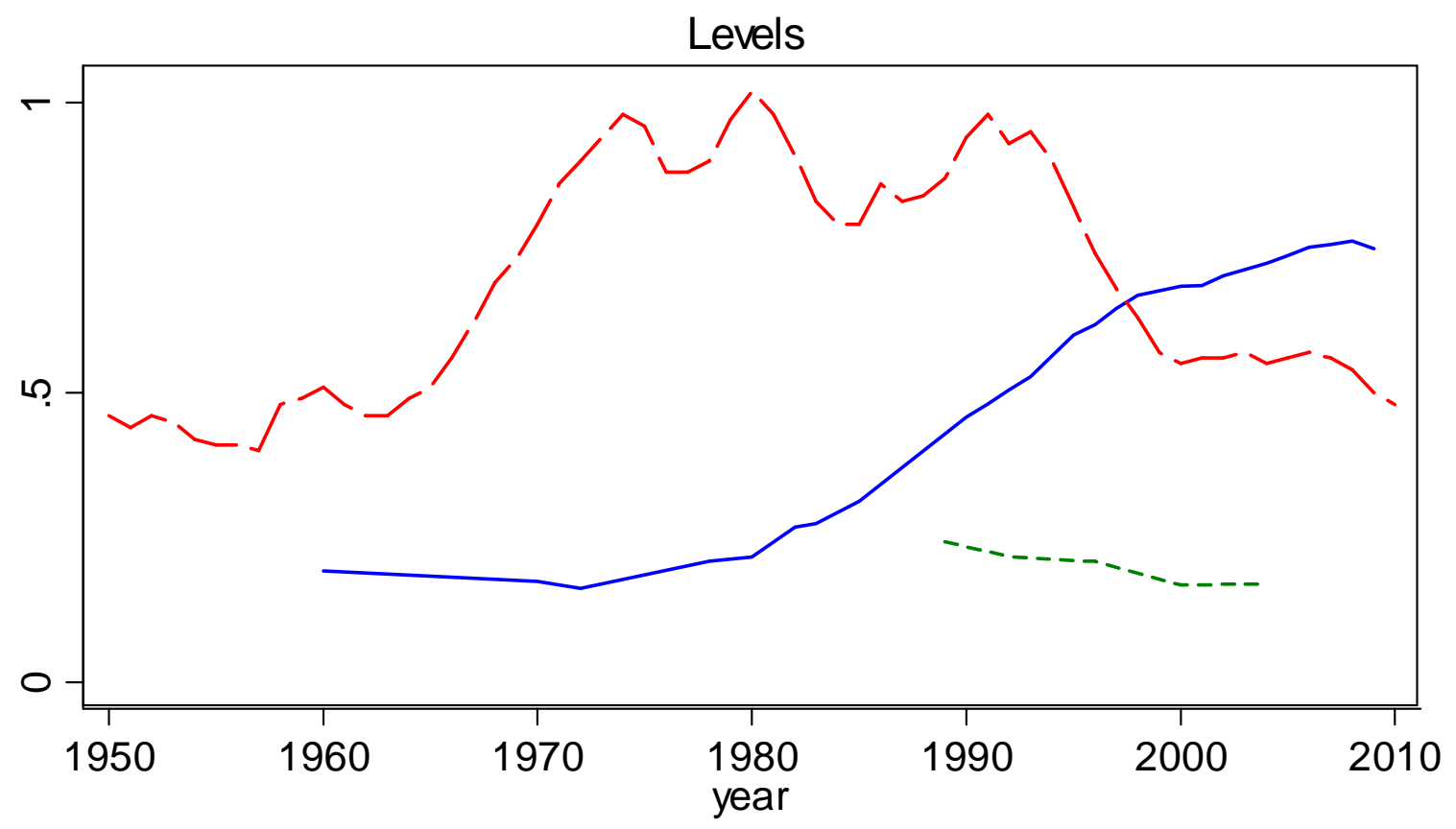

Logs, net of annual constant-sample world mean

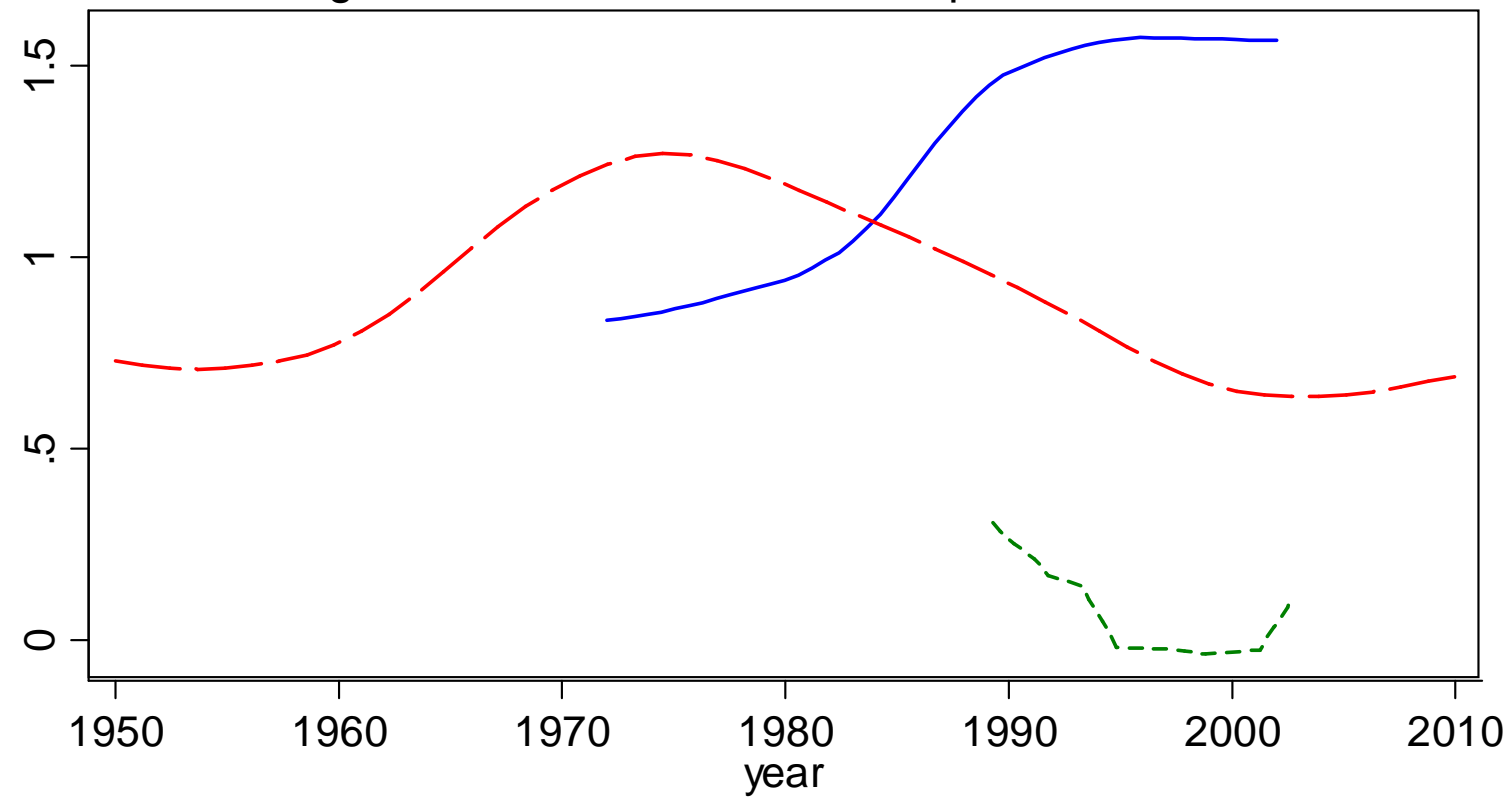


Figure 6: Residual US crime and punishment over time

\section{Residual US crime and punishment over time (logs)}

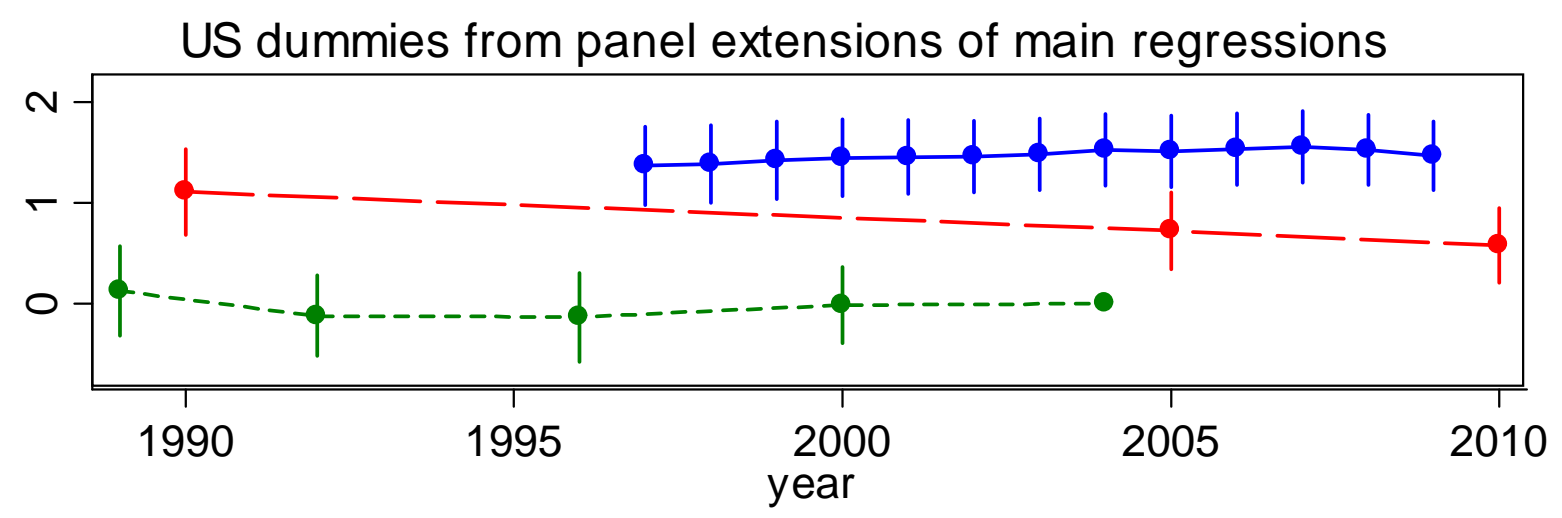

Domestic data minus prediction from main regressions

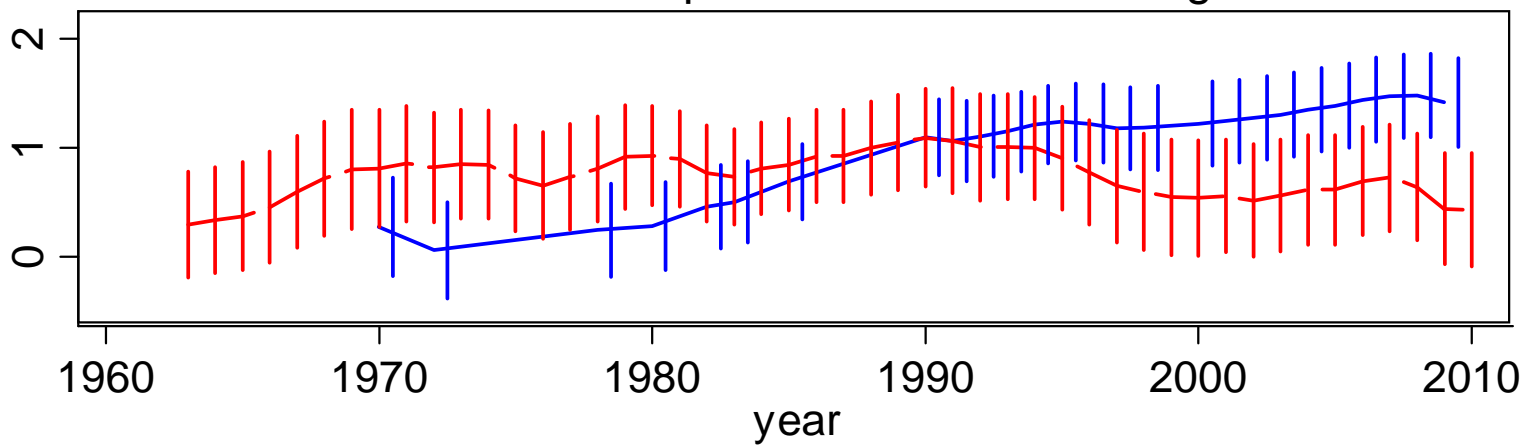

US dummies from panel regressions using UNCTS/WHO data

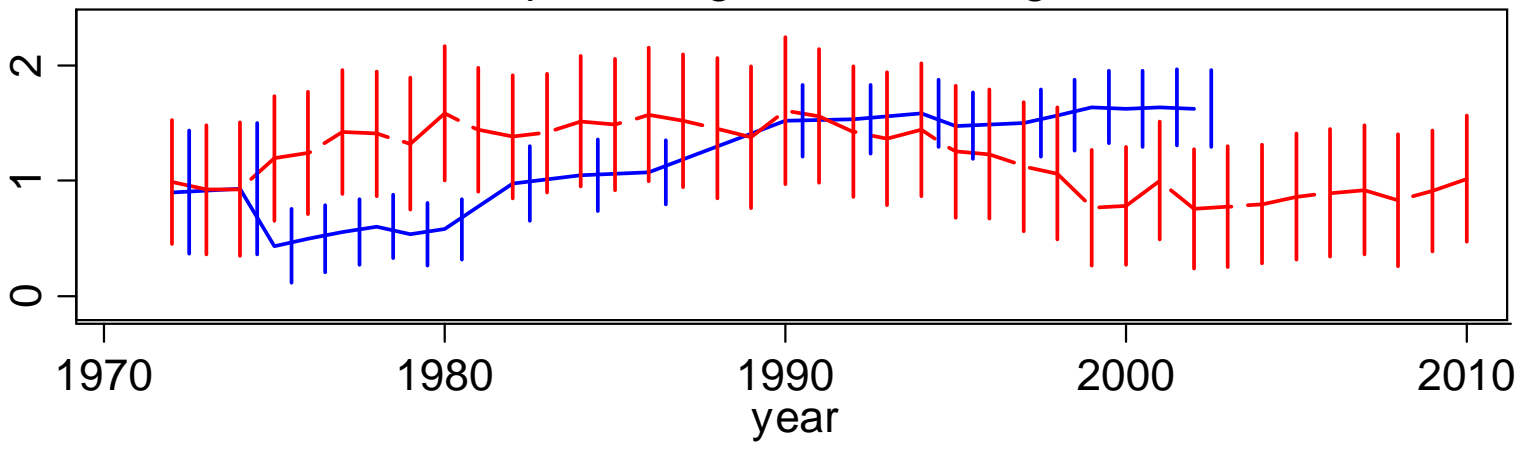

\section{residual incarceration \\ residual homicide}

--_------ residual victimization

Spikes indicate 95\% confidence intervals. Standard errors are clustered at the country level (graphs 1 and 3). All scales are in logs. Graphs 1 and 3 show estimated US dummies from pooled panel regressions with missing dummies for indep. variables and a quadratic trend. Graph 2 shows the log ratio of actual US values (from BJS and UCR) to cross-sectional predictions from models 3 and 7 of table 1 , adjusted for homicide reporting differences.

Graph 1 uses the same data and countries as tables 1 and 2 , but pools data from all available years.

Graph 3 uses as dependent variables data from the UN and WHO, and the same independent variables as tables 1-3 except:

(1) Gini (replaced by UTIP's measure), (2) labor laws, unemployment, and teen birth rates (omitted for lack of data). 
Figure 7: Residual US latent crime, by elasticity

\section{Confidence intervals for residual US latent crime by crime-punishment elasticity}
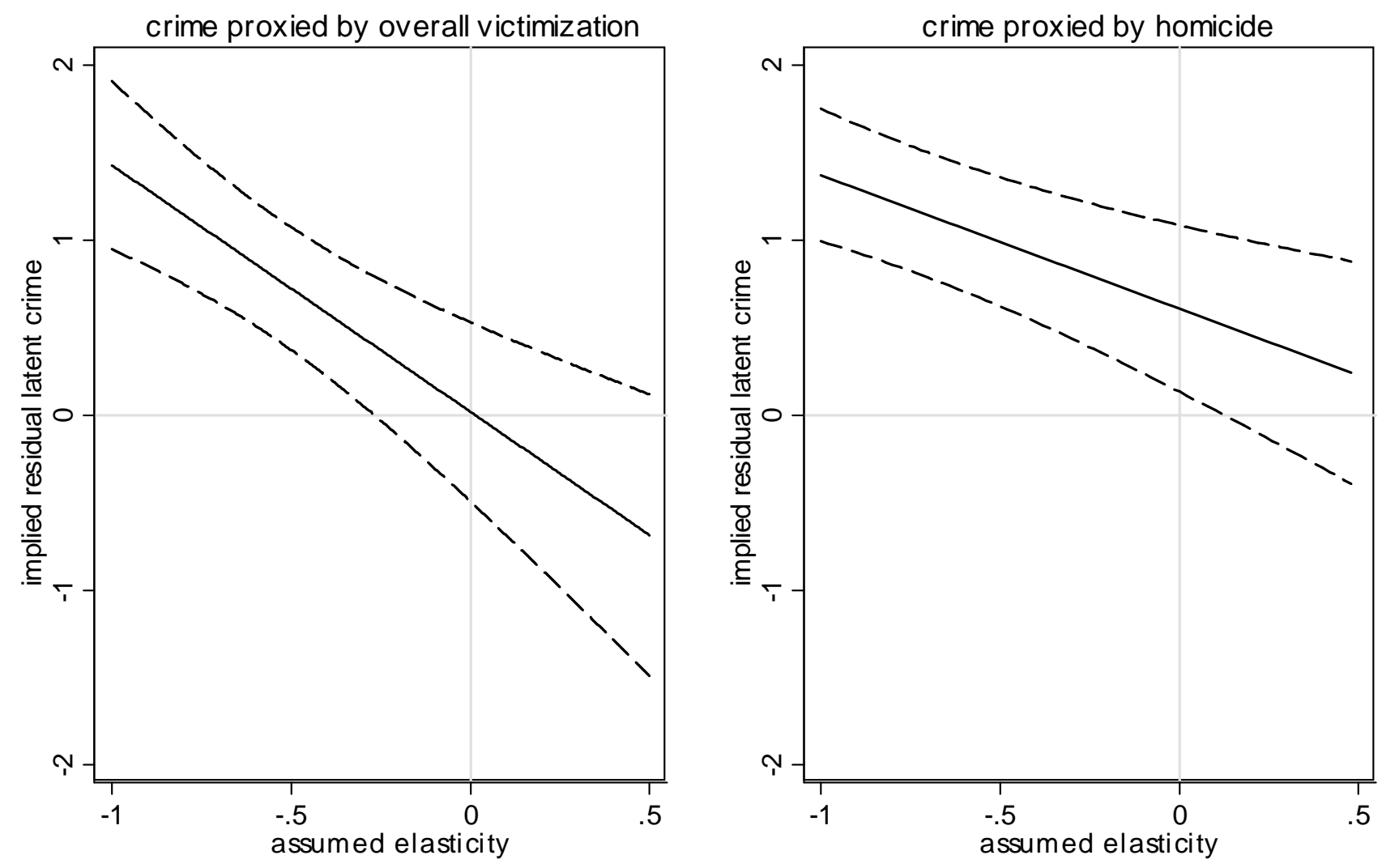

Point estimates and $95 \%$ confidence intervals from linear combinations of reg ression coefficients (see formula in section 5.2). The right plot has been drawn using MI estimates. The left plot derives from regressions with dummies indicating missing values. 
Figure 8: Individual US states vs OECD countries

Homicides and incarceration: US states vs OECD countries

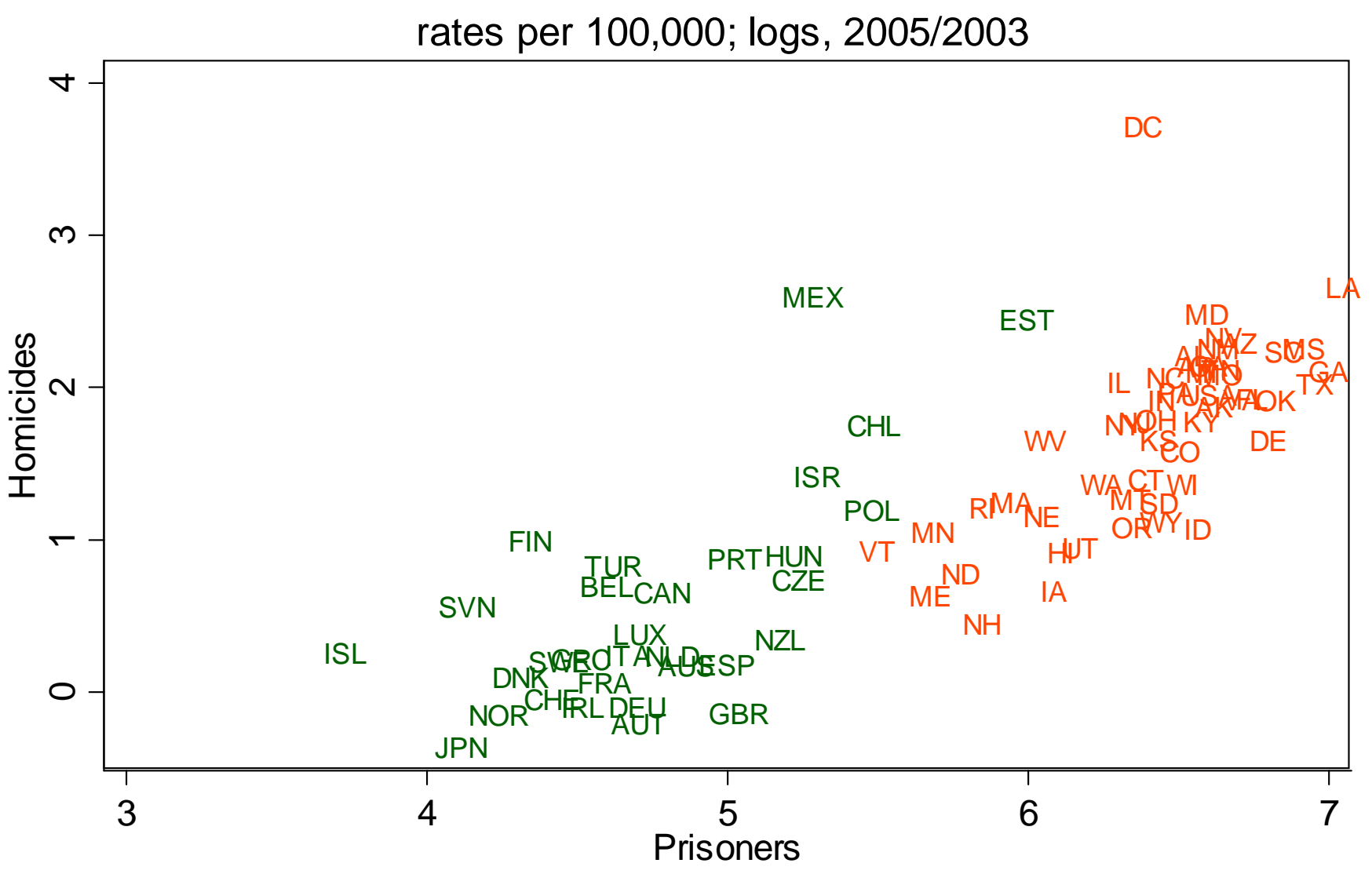

Source: IHME-GBD and ICPS (OECD); UCR and BJS (US states) 
Table 1: Homicides and Incarceration

\begin{tabular}{|c|c|c|c|c|c|c|c|c|}
\hline & \multicolumn{4}{|c|}{ Homicide rate (2005) } & \multicolumn{4}{|c|}{ Incarceration rate (2005) } \\
\hline & OLS & OLS+ & $\mathrm{Ml}$ & FIML & OLS & OLS+ & $\mathrm{Ml}$ & FIML \\
\hline USA dummy & $\begin{array}{l}0.84 * * * \\
(0.26)\end{array}$ & $\begin{array}{l}0.62^{* * *} \\
(0.23)\end{array}$ & $\begin{array}{l}0.62 * * \\
(0.26)\end{array}$ & $\begin{array}{l}0.55^{* *} \\
(0.22)\end{array}$ & $\begin{array}{l}1.57^{* * *} \\
(0.17)\end{array}$ & $\begin{array}{l}1.44^{* * *} \\
(0.20)\end{array}$ & $\begin{array}{l}1.37^{* * *} \\
(0.20)\end{array}$ & $\begin{array}{l}1.35^{* * *} \\
(0.18)\end{array}$ \\
\hline GDP per capita & $\begin{array}{l}-0.02 \\
(0.02)\end{array}$ & $\begin{array}{l}-0.02 \\
(0.01)\end{array}$ & $\begin{array}{l}-0.01 \\
(0.01)\end{array}$ & $\begin{array}{l}-0.01 \\
(0.01)\end{array}$ & $\begin{array}{l}-0.01 \\
(0.01)\end{array}$ & $\begin{array}{l}-0.01 \\
(0.01)\end{array}$ & $\begin{array}{l}-0.00 \\
(0.01)\end{array}$ & $\begin{array}{l}-0.00 \\
(0.01)\end{array}$ \\
\hline In(GDP per capita) & $\begin{array}{l}0.31 \\
(0.26)\end{array}$ & $\begin{array}{l}-0.06 \\
(0.11)\end{array}$ & $\begin{array}{l}0.01 \\
(0.14)\end{array}$ & $\begin{array}{l}0.02 \\
(0.13)\end{array}$ & $\begin{array}{l}0.27 * \\
(0.14)\end{array}$ & $\begin{array}{l}0.30 * * * \\
(0.10)\end{array}$ & $\begin{array}{l}0.33^{* *} \\
(0.16)\end{array}$ & $\begin{array}{l}0.35^{* * *} \\
(0.13)\end{array}$ \\
\hline English legal origin & $\begin{array}{l}-0.35 \\
(0.26)\end{array}$ & $\begin{array}{l}0.00 \\
(0.16)\end{array}$ & $\begin{array}{l}-0.14 \\
(0.18)\end{array}$ & $\begin{array}{l}-0.16 \\
(0.17)\end{array}$ & $\begin{array}{l}0.06 \\
(0.18)\end{array}$ & $\begin{array}{l}0.08 \\
(0.15)\end{array}$ & $\begin{array}{l}-0.05 \\
(0.16)\end{array}$ & $\begin{array}{l}-0.07 \\
(0.15)\end{array}$ \\
\hline Socialist legal origin & $\begin{array}{l}0.41 \\
(0.31)\end{array}$ & $\begin{array}{l}0.38^{*} \\
(0.21)\end{array}$ & $\begin{array}{l}0.11 \\
(0.26)\end{array}$ & $\begin{array}{l}0.04 \\
(0.26)\end{array}$ & $\begin{array}{l}0.67 * * * \\
(0.21)\end{array}$ & $\begin{array}{l}0.66 * * * \\
(0.18)\end{array}$ & $\begin{array}{l}0.30 \\
(0.21)\end{array}$ & $\begin{array}{l}0.27 \\
(0.19)\end{array}$ \\
\hline Federal state & $\begin{array}{l}0.18 \\
(0.22)\end{array}$ & $\begin{array}{l}0.20 \\
(0.18)\end{array}$ & $\begin{array}{l}0.12 \\
(0.19)\end{array}$ & $\begin{array}{l}0.13 \\
(0.18)\end{array}$ & $\begin{array}{l}-0.15 \\
(0.13)\end{array}$ & $\begin{array}{l}-0.11 \\
(0.13)\end{array}$ & $\begin{array}{l}-0.15 \\
(0.13)\end{array}$ & $\begin{array}{l}-0.15 \\
(0.12)\end{array}$ \\
\hline Democracy & $\begin{array}{l}0.79 * * \\
(0.31)\end{array}$ & $\begin{array}{l}0.14 \\
(0.16)\end{array}$ & $\begin{array}{l}0.36 \\
(0.25)\end{array}$ & $\begin{array}{l}0.45^{*} \\
(0.24)\end{array}$ & $\begin{array}{l}-0.33 \\
(0.22)\end{array}$ & $\begin{array}{l}-0.12 \\
(0.17)\end{array}$ & $\begin{array}{l}0.07 \\
(0.18)\end{array}$ & $\begin{array}{l}0.10 \\
(0.16)\end{array}$ \\
\hline Proportional voting & $\begin{array}{l}0.10 \\
(0.20)\end{array}$ & $\begin{array}{l}-0.08 \\
(0.16)\end{array}$ & $\begin{array}{l}-0.05 \\
(0.17)\end{array}$ & $\begin{array}{l}-0.06 \\
(0.16)\end{array}$ & $\begin{array}{l}-0.21 \\
(0.15)\end{array}$ & $\begin{array}{l}-0.24^{*} \\
(0.13)\end{array}$ & $\begin{array}{l}-0.28 * \\
(0.14)\end{array}$ & $\begin{array}{l}-0.27^{* *} \\
(0.13)\end{array}$ \\
\hline Freedom & $\begin{array}{l}-1.71^{* * *} \\
(0.47)\end{array}$ & $\begin{array}{l}-0.18 \\
(0.33)\end{array}$ & $\begin{array}{l}-0.38 \\
(0.38)\end{array}$ & $\begin{array}{l}-0.34 \\
(0.34)\end{array}$ & $\begin{array}{l}0.25 \\
(0.46)\end{array}$ & $\begin{array}{l}0.18 \\
(0.26)\end{array}$ & $\begin{array}{l}0.15 \\
(0.30)\end{array}$ & $\begin{array}{l}0.18 \\
(0.29)\end{array}$ \\
\hline Protestant/pop. & $\begin{array}{l}0.42 \\
(0.56)\end{array}$ & $\begin{array}{l}0.50 \\
(0.33)\end{array}$ & $\begin{array}{l}0.14 \\
(0.41)\end{array}$ & $\begin{array}{l}0.04 \\
(0.37)\end{array}$ & $\begin{array}{l}-0.72 * * \\
(0.31)\end{array}$ & $\begin{array}{l}-0.48 \\
(0.30)\end{array}$ & $\begin{array}{l}-0.86 * * * \\
(0.33)\end{array}$ & $\begin{array}{l}-0.92^{* * *} \\
(0.31)\end{array}$ \\
\hline Catholic/pop. & $\begin{array}{l}-0.07 \\
(0.41)\end{array}$ & $\begin{array}{l}0.27 \\
(0.25)\end{array}$ & $\begin{array}{l}0.02 \\
(0.31)\end{array}$ & $\begin{array}{l}-0.07 \\
(0.31)\end{array}$ & $\begin{array}{l}-0.37 \\
(0.28)\end{array}$ & $\begin{array}{l}-0.22 \\
(0.22)\end{array}$ & $\begin{array}{l}-0.40 \\
(0.25)\end{array}$ & $\begin{array}{l}-0.45^{*} \\
(0.24)\end{array}$ \\
\hline Muslim/pop. & $\begin{array}{l}-1.07^{* *} \\
(0.50)\end{array}$ & $\begin{array}{l}-0.70 * * * \\
(0.26)\end{array}$ & $\begin{array}{l}-0.79 * * \\
(0.32)\end{array}$ & $\begin{array}{l}-0.79 * * * \\
(0.28)\end{array}$ & $\begin{array}{l}-0.64^{*} \\
(0.37)\end{array}$ & $\begin{array}{l}-0.51^{* *} \\
(0.25)\end{array}$ & $\begin{array}{l}-0.56^{*} \\
(0.30)\end{array}$ & $\begin{array}{l}-0.57^{* *} \\
(0.29)\end{array}$ \\
\hline Slave descendants/pop. & $\begin{array}{l}0.08 \\
(1.32)\end{array}$ & $\begin{array}{l}0.49 \\
(0.34)\end{array}$ & $\begin{array}{l}-0.40 \\
(0.94)\end{array}$ & $\begin{array}{l}-0.80 \\
(0.71)\end{array}$ & $\begin{array}{l}-0.03 \\
(0.65)\end{array}$ & $\begin{array}{l}0.27 \\
(0.41)\end{array}$ & $\begin{array}{l}-0.75 \\
(0.75)\end{array}$ & $\begin{array}{l}-0.99 \\
(0.69)\end{array}$ \\
\hline Ethnic fractionalization & $\begin{array}{l}0.47 \\
(0.45)\end{array}$ & $\begin{array}{l}0.21 \\
(0.29)\end{array}$ & $\begin{array}{l}0.44 \\
(0.30)\end{array}$ & $\begin{array}{l}0.44 \\
(0.27)\end{array}$ & $\begin{array}{l}0.31 \\
(0.25)\end{array}$ & $\begin{array}{l}0.17 \\
(0.26)\end{array}$ & $\begin{array}{l}0.27 \\
(0.28)\end{array}$ & $\begin{array}{l}0.28 \\
(0.25)\end{array}$ \\
\hline Immigrants/pop. & $\begin{array}{l}0.88 \\
(1.11)\end{array}$ & $\begin{array}{l}0.94 \\
(0.65)\end{array}$ & $\begin{array}{l}0.52 \\
(0.76)\end{array}$ & $\begin{array}{l}0.60 \\
(0.69)\end{array}$ & $\begin{array}{l}0.49 \\
(0.82)\end{array}$ & $\begin{array}{l}0.47 \\
(0.60)\end{array}$ & $\begin{array}{l}0.33 \\
(0.61)\end{array}$ & $\begin{array}{l}0.34 \\
(0.53)\end{array}$ \\
\hline Urban/pop. & $\begin{array}{l}-1.11^{*} \\
(0.59)\end{array}$ & $\begin{array}{l}-0.12 \\
(0.40)\end{array}$ & $\begin{array}{l}0.04 \\
(0.43)\end{array}$ & $\begin{array}{l}0.05 \\
(0.41)\end{array}$ & $\begin{array}{l}0.28 \\
(0.44)\end{array}$ & $\begin{array}{l}0.26 \\
(0.35)\end{array}$ & $\begin{array}{l}0.44 \\
(0.36)\end{array}$ & $\begin{array}{l}0.46 \\
(0.35)\end{array}$ \\
\hline Males 15-19/pop. & $\begin{array}{l}25.16 \\
(19.66)\end{array}$ & $\begin{array}{l}34.39 * * * \\
(12.52)\end{array}$ & $\begin{array}{l}31.41^{* *} \\
(13.33)\end{array}$ & $\begin{array}{l}34.09 * * * \\
(12.62)\end{array}$ & $\begin{array}{l}21.86 * \\
(11.93)\end{array}$ & $\begin{array}{l}21.02 * * \\
(10.02)\end{array}$ & $\begin{array}{l}23.10^{* *} \\
(11.23)\end{array}$ & $\begin{array}{l}25.32 * * \\
(10.23)\end{array}$ \\
\hline Teen/total births (t-25) & $\begin{array}{l}3.80 \\
(2.30)\end{array}$ & $\begin{array}{l}3.49 * * * \\
(1.23)\end{array}$ & $\begin{array}{l}4.51 \\
(2.74)\end{array}$ & $\begin{array}{l}5.71 * * \\
(2.42)\end{array}$ & $\begin{array}{l}1.21 \\
(1.37)\end{array}$ & $\begin{array}{l}2.44^{* * *} \\
(0.93)\end{array}$ & $\begin{array}{l}5.21^{* * *} \\
(1.65)\end{array}$ & $\begin{array}{l}5.73^{* * *} \\
(1.46)\end{array}$ \\
\hline Gini & $\begin{array}{l}5.23^{* * *} \\
(1.39)\end{array}$ & $\begin{array}{l}3.14^{* * *} \\
(0.89)\end{array}$ & $\begin{array}{l}2.79 * * \\
(1.10)\end{array}$ & $\begin{array}{l}2.66 * * * \\
(0.99)\end{array}$ & $\begin{array}{l}1.32 \\
(1.11)\end{array}$ & $\begin{array}{l}1.19 \\
(0.77)\end{array}$ & $\begin{array}{l}0.24 \\
(0.92)\end{array}$ & $\begin{array}{l}0.10 \\
(0.81)\end{array}$ \\
\hline Difficulty firing worker & $\begin{array}{l}-0.26 \\
(0.37)\end{array}$ & $\begin{array}{l}-0.21 \\
(0.30)\end{array}$ & $\begin{array}{l}-0.38 \\
(0.32)\end{array}$ & $\begin{array}{l}-0.35 \\
(0.28)\end{array}$ & $\begin{array}{l}0.20 \\
(0.32)\end{array}$ & $\begin{array}{l}0.05 \\
(0.24)\end{array}$ & $\begin{array}{l}0.07 \\
(0.27)\end{array}$ & $\begin{array}{l}0.07 \\
(0.27)\end{array}$ \\
\hline Unemployment rate & $\begin{array}{l}2.11 \\
(3.36) \\
\end{array}$ & $\begin{array}{l}2.63^{*} \\
(1.42) \\
\end{array}$ & $\begin{array}{l}3.93^{*} \\
(2.23) \\
\end{array}$ & $\begin{array}{l}4.84 * * \\
(2.14) \\
\end{array}$ & $\begin{array}{l}1.93 \\
(1.77) \\
\end{array}$ & $\begin{array}{l}0.70 \\
(1.06) \\
\end{array}$ & $\begin{array}{l}2.47 \\
(1.82) \\
\end{array}$ & $\begin{array}{l}2.91^{*} \\
(1.58)\end{array}$ \\
\hline Observations & 67 & 183 & 183 & 183 & 67 & 172 & 172 & 172 \\
\hline$R^{2}$ & 0.85 & 0.62 & & & 0.69 & 0.53 & & \\
\hline joint $p$-value & 0.000 & 0.000 & 0.000 & 0.000 & 0.000 & 0.000 & 0.000 & 0.000 \\
\hline
\end{tabular}


Table 2: Victimization (ICVS 1989-2005)

\begin{tabular}{|c|c|c|c|c|c|c|}
\hline & Overall & Car theft & Burglary & Theft & Robbery & Assault \\
\hline USA dummy & $\begin{array}{l}-0.04 \\
(0.19)\end{array}$ & $\begin{array}{l}-0.18 \\
(0.40)\end{array}$ & $\begin{array}{l}0.30 \\
(0.38)\end{array}$ & $\begin{array}{l}-0.11 \\
(0.28)\end{array}$ & $\begin{array}{l}-0.09 \\
(0.38)\end{array}$ & $\begin{array}{l}-0.23 \\
(0.26)\end{array}$ \\
\hline GDP per capita & $\begin{array}{l}0.001 \\
(0.006)\end{array}$ & $\begin{array}{l}-0.029 * \\
(0.017)\end{array}$ & $\begin{array}{l}-0.003 \\
(0.010)\end{array}$ & $\begin{array}{l}0.007 \\
(0.012)\end{array}$ & $\begin{array}{l}-0.007 \\
(0.012)\end{array}$ & $\begin{array}{l}0.001 \\
(0.011)\end{array}$ \\
\hline In(GDP per capita) & $\begin{array}{l}-0.09 \\
(0.12)\end{array}$ & $\begin{array}{l}-0.12 \\
(0.32)\end{array}$ & $\begin{array}{l}0.04 \\
(0.22)\end{array}$ & $\begin{array}{l}-0.30^{*} \\
(0.18)\end{array}$ & $\begin{array}{l}-0.40^{*} \\
(0.23)\end{array}$ & $\begin{array}{l}-0.28^{*} \\
(0.16)\end{array}$ \\
\hline English legal origin & $\begin{array}{l}0.24 \\
(0.16)\end{array}$ & $\begin{array}{l}1.28^{* * *} \\
(0.35)\end{array}$ & $\begin{array}{l}0.04 \\
(0.26)\end{array}$ & $\begin{array}{l}0.32 \\
(0.26)\end{array}$ & $\begin{array}{l}0.32 \\
(0.34)\end{array}$ & $\begin{array}{l}0.68^{* * *} \\
(0.22)\end{array}$ \\
\hline Socialist legal origin & $\begin{array}{l}0.10 \\
(0.16)\end{array}$ & $\begin{array}{l}0.05 \\
(0.44)\end{array}$ & $\begin{array}{l}-0.18 \\
(0.27)\end{array}$ & $\begin{array}{l}0.23 \\
(0.24)\end{array}$ & $\begin{array}{l}0.31 \\
(0.32)\end{array}$ & $\begin{array}{l}0.25 \\
(0.22)\end{array}$ \\
\hline Federal state & $\begin{array}{l}0.02 \\
(0.09)\end{array}$ & $\begin{array}{l}-0.27 \\
(0.28)\end{array}$ & $\begin{array}{l}-0.30 * \\
(0.16)\end{array}$ & $\begin{array}{l}0.18 \\
(0.13)\end{array}$ & $\begin{array}{l}0.02 \\
(0.19)\end{array}$ & $\begin{array}{l}-0.09 \\
(0.13)\end{array}$ \\
\hline Democracy & $\begin{array}{l}-0.37 \\
(0.23)\end{array}$ & $\begin{array}{l}-0.01 \\
(0.44)\end{array}$ & $\begin{array}{l}-0.51 \\
(0.39)\end{array}$ & $\begin{array}{l}-0.26 \\
(0.28)\end{array}$ & $\begin{array}{l}-0.03 \\
(0.35)\end{array}$ & $\begin{array}{l}-0.34 \\
(0.28)\end{array}$ \\
\hline Proportional voting & $\begin{array}{l}0.34^{* * *} \\
(0.12)\end{array}$ & $\begin{array}{l}0.71^{* *} \\
(0.28)\end{array}$ & $\begin{array}{l}0.23 \\
(0.22)\end{array}$ & $\begin{array}{l}0.30 * \\
(0.17)\end{array}$ & $\begin{array}{l}0.53^{* *} \\
(0.26)\end{array}$ & $\begin{array}{l}0.38^{* *} \\
(0.17)\end{array}$ \\
\hline Freedom & $\begin{array}{l}-0.06 \\
(0.30)\end{array}$ & $\begin{array}{l}-1.07 \\
(0.81)\end{array}$ & $\begin{array}{l}0.13 \\
(0.55)\end{array}$ & $\begin{array}{l}-0.21 \\
(0.48)\end{array}$ & $\begin{array}{l}-0.83 \\
(0.64)\end{array}$ & $\begin{array}{l}-0.33 \\
(0.36)\end{array}$ \\
\hline Protestant/pop. & $\begin{array}{l}0.00 \\
(0.19)\end{array}$ & $\begin{array}{l}0.60 \\
(0.47)\end{array}$ & $\begin{array}{l}-0.59 \\
(0.41)\end{array}$ & $\begin{array}{l}0.41 \\
(0.44)\end{array}$ & $\begin{array}{l}0.31 \\
(0.47)\end{array}$ & $\begin{array}{l}0.58^{*} \\
(0.34)\end{array}$ \\
\hline Catholic/pop. & $\begin{array}{l}-0.14 \\
(0.17)\end{array}$ & $\begin{array}{l}1.00^{* * *} \\
(0.34)\end{array}$ & $\begin{array}{l}-0.33 \\
(0.31)\end{array}$ & $\begin{array}{l}0.21 \\
(0.37)\end{array}$ & $\begin{array}{l}0.48 \\
(0.38)\end{array}$ & $\begin{array}{l}-0.08 \\
(0.28)\end{array}$ \\
\hline Muslim/pop. & $\begin{array}{l}-0.30 \\
(0.28)\end{array}$ & $\begin{array}{l}1.38^{* *} \\
(0.59)\end{array}$ & $\begin{array}{l}-0.35 \\
(0.48)\end{array}$ & $\begin{array}{l}0.07 \\
(0.44)\end{array}$ & $\begin{array}{l}0.49 \\
(0.52)\end{array}$ & $\begin{array}{l}-0.63^{* *} \\
(0.30)\end{array}$ \\
\hline Slave descendants/pop. & $\begin{array}{l}0.61 \\
(2.85)\end{array}$ & $\begin{array}{l}4.05 \\
(4.21)\end{array}$ & $\begin{array}{l}-3.60 \\
(5.23)\end{array}$ & $\begin{array}{l}-0.94 \\
(4.42)\end{array}$ & $\begin{array}{l}0.18 \\
(4.03)\end{array}$ & $\begin{array}{l}5.04 \\
(3.70)\end{array}$ \\
\hline Ethnic fractionalization & $\begin{array}{l}-0.01 \\
(0.21)\end{array}$ & $\begin{array}{l}-0.28 \\
(0.47)\end{array}$ & $\begin{array}{l}0.24 \\
(0.31)\end{array}$ & $\begin{array}{l}-0.24 \\
(0.28)\end{array}$ & $\begin{array}{l}-0.08 \\
(0.35)\end{array}$ & $\begin{array}{l}0.15 \\
(0.21)\end{array}$ \\
\hline Immigrants/pop. & $\begin{array}{l}0.25 \\
(0.61)\end{array}$ & $\begin{array}{l}2.13 \\
(2.19)\end{array}$ & $\begin{array}{l}0.96 \\
(1.37)\end{array}$ & $\begin{array}{l}1.57 \\
(1.45)\end{array}$ & $\begin{array}{l}2.36^{*} \\
(1.35)\end{array}$ & $\begin{array}{l}1.88^{*} \\
(1.12)\end{array}$ \\
\hline Urban/pop. & $\begin{array}{l}0.82^{* *} \\
(0.34)\end{array}$ & $\begin{array}{l}3.67^{* * *} \\
(0.96)\end{array}$ & $\begin{array}{l}0.44 \\
(0.63)\end{array}$ & $\begin{array}{l}0.83 \\
(0.53)\end{array}$ & $\begin{array}{l}1.94^{* *} \\
(0.81)\end{array}$ & $\begin{array}{l}0.98^{* *} \\
(0.45)\end{array}$ \\
\hline Males 15-19/pop. & $\begin{array}{l}8.03 \\
(7.70)\end{array}$ & $\begin{array}{l}-19.9 \\
(18.8)\end{array}$ & $\begin{array}{l}25.2^{*} \\
(14.5)\end{array}$ & $\begin{array}{l}9.61 \\
(14.6)\end{array}$ & $\begin{array}{l}8.23 \\
(18.3)\end{array}$ & $\begin{array}{l}12.2 \\
(12.1)\end{array}$ \\
\hline Teen/total births (t-25) & $\begin{array}{l}0.21 \\
(1.72)\end{array}$ & $\begin{array}{l}4.06 \\
(3.65)\end{array}$ & $\begin{array}{l}2.08 \\
(2.78)\end{array}$ & $\begin{array}{l}2.98 \\
(2.76)\end{array}$ & $\begin{array}{l}1.72 \\
(3.27)\end{array}$ & $\begin{array}{l}0.31 \\
(2.07)\end{array}$ \\
\hline Gini & $\begin{array}{l}0.68 \\
(0.67)\end{array}$ & $\begin{array}{l}-0.15 \\
(1.79)\end{array}$ & $\begin{array}{l}1.97 \\
(1.29)\end{array}$ & $\begin{array}{l}-0.53 \\
(1.27)\end{array}$ & $\begin{array}{l}3.85^{* * *} \\
(1.44)\end{array}$ & $\begin{array}{l}-0.25 \\
(1.20)\end{array}$ \\
\hline Difficulty firing worker & $\begin{array}{l}-0.15 \\
(0.20)\end{array}$ & $\begin{array}{l}-0.70 \\
(0.43)\end{array}$ & $\begin{array}{l}-0.56 \\
(0.35)\end{array}$ & $\begin{array}{l}-0.00 \\
(0.32)\end{array}$ & $\begin{array}{l}-0.38 \\
(0.41)\end{array}$ & $\begin{array}{l}-0.02 \\
(0.30)\end{array}$ \\
\hline Unemployment rate & $\begin{array}{c}-0.06 \\
(0.63)\end{array}$ & $\begin{array}{l}2.14 \\
(1.64)\end{array}$ & $\begin{array}{l}-0.43 \\
(1.02)\end{array}$ & $\begin{array}{l}-0.01 \\
(1.01)\end{array}$ & $\begin{array}{l}0.05 \\
(1.21)\end{array}$ & $\begin{array}{l}0.40 \\
(0.80)\end{array}$ \\
\hline Observations & 139 & 138 & 139 & 139 & 139 & 139 \\
\hline Clusters (countries) & 72 & 72 & 72 & 72 & 72 & 72 \\
\hline joint $p$-value & 0.010 & 0.000 & 0.003 & 0.221 & 0.000 & 0.000 \\
\hline
\end{tabular}

All dependent variables are log-transformed. Missing data on indep. variables multiply imputed. Pooled OLS with sweep and surveytype fixed effects, and equal country-weighting.

Country-clustered standard errors in parentheses. 
Table 3: Drugs

\begin{tabular}{|c|c|c|c|c|}
\hline & deaths & cocaine & ecstasy & opiates \\
\hline USA dummy & $\begin{array}{l}0.54^{* *} \\
(0.26)\end{array}$ & $\begin{array}{l}-0.09 \\
(0.48)\end{array}$ & $\begin{array}{l}-0.14 \\
(0.43)\end{array}$ & $\begin{array}{l}1.28^{*} \\
(0.66)\end{array}$ \\
\hline GDP per capita & $\begin{array}{l}0.00 \\
(0.01)\end{array}$ & $\begin{array}{l}0.03 \\
(0.02)\end{array}$ & $\begin{array}{l}0.05^{*} \\
(0.03)\end{array}$ & $\begin{array}{l}-0.04 \\
(0.03)\end{array}$ \\
\hline In(GDP per capita) & $\begin{array}{l}0.43^{* * *} \\
(0.14)\end{array}$ & $\begin{array}{l}-0.63^{*} \\
(0.34)\end{array}$ & $\begin{array}{l}-0.42 \\
(0.38)\end{array}$ & $\begin{array}{l}0.15 \\
(0.37)\end{array}$ \\
\hline English legal origin & $\begin{array}{l}0.05 \\
(0.20)\end{array}$ & $\begin{array}{l}1.49 * * * \\
(0.39)\end{array}$ & $\begin{array}{l}0.90 * * \\
(0.38)\end{array}$ & $\begin{array}{l}0.47 \\
(0.52)\end{array}$ \\
\hline Socialist legal origin & $\begin{array}{l}0.44 \\
(0.31)\end{array}$ & $\begin{array}{l}0.31 \\
(0.56)\end{array}$ & $\begin{array}{l}1.57^{* * *} \\
(0.39)\end{array}$ & $\begin{array}{l}0.73 \\
(0.53)\end{array}$ \\
\hline Federal state & $\begin{array}{l}0.13 \\
(0.18)\end{array}$ & $\begin{array}{l}0.34 \\
(0.23)\end{array}$ & $\begin{array}{l}0.00 \\
(0.27)\end{array}$ & $\begin{array}{l}-0.18 \\
(0.42)\end{array}$ \\
\hline Democracy & $\begin{array}{l}0.26 \\
(0.23)\end{array}$ & $\begin{array}{l}0.18 \\
(0.45)\end{array}$ & $\begin{array}{l}-0.14 \\
(0.38)\end{array}$ & $\begin{array}{l}0.15 \\
(0.42)\end{array}$ \\
\hline Proportional voting & $\begin{array}{l}-0.23 \\
(0.17)\end{array}$ & $\begin{array}{l}0.45 \\
(0.34)\end{array}$ & $\begin{array}{l}-0.01 \\
(0.31)\end{array}$ & $\begin{array}{l}-0.65 \\
(0.45)\end{array}$ \\
\hline Freedom & $\begin{array}{l}0.10 \\
(0.37)\end{array}$ & $\begin{array}{l}0.85 \\
(0.58)\end{array}$ & $\begin{array}{l}0.36 \\
(0.56)\end{array}$ & $\begin{array}{l}0.68 \\
(0.73)\end{array}$ \\
\hline Protestant/pop. & $\begin{array}{l}1.72 * * * \\
(0.43)\end{array}$ & $\begin{array}{l}0.93 \\
(0.62)\end{array}$ & $\begin{array}{l}-0.44 \\
(0.71)\end{array}$ & $\begin{array}{l}-1.20 \\
(1.21)\end{array}$ \\
\hline Catholic/pop. & $\begin{array}{l}0.14 \\
(0.34)\end{array}$ & $\begin{array}{l}1.68 * * * \\
(0.45)\end{array}$ & $\begin{array}{l}0.21 \\
(0.48)\end{array}$ & $\begin{array}{l}-0.86 \\
(0.85)\end{array}$ \\
\hline Muslim/pop. & $\begin{array}{l}0.20 \\
(0.33)\end{array}$ & $\begin{array}{l}0.57 \\
(1.02)\end{array}$ & $\begin{array}{l}0.89 \\
(1.05)\end{array}$ & $\begin{array}{l}0.22 \\
(0.78)\end{array}$ \\
\hline Slave descendants/pop. & $\begin{array}{l}-0.65 \\
(0.91)\end{array}$ & $\begin{array}{l}0.67 \\
(1.37)\end{array}$ & $\begin{array}{l}0.78 \\
(1.48)\end{array}$ & $\begin{array}{l}1.19 \\
(1.82)\end{array}$ \\
\hline Ethnic fractionalization & $\begin{array}{l}-0.18 \\
(0.32)\end{array}$ & $\begin{array}{l}-0.90^{*} \\
(0.51)\end{array}$ & $\begin{array}{l}0.27 \\
(0.55)\end{array}$ & $\begin{array}{l}0.69 \\
(0.69)\end{array}$ \\
\hline Immigrants/pop. & $\begin{array}{l}1.65^{* *} \\
(0.79)\end{array}$ & $\begin{array}{l}-0.78 \\
(1.50)\end{array}$ & $\begin{array}{l}3.20 \\
(1.97)\end{array}$ & $\begin{array}{l}0.62 \\
(1.60)\end{array}$ \\
\hline Urban/pop. & $\begin{array}{l}-0.72 \\
(0.47)\end{array}$ & $\begin{array}{l}1.95^{*} \\
(0.99)\end{array}$ & $\begin{array}{l}0.27 \\
(0.98)\end{array}$ & $\begin{array}{l}-0.00 \\
(0.87)\end{array}$ \\
\hline Males 15-19/pop. & $\begin{array}{l}11.31 \\
(13.47)\end{array}$ & $\begin{array}{l}-39.20 \\
(26.00)\end{array}$ & $\begin{array}{l}-50.01^{*} \\
(25.86)\end{array}$ & $\begin{array}{l}0.76 \\
(27.67)\end{array}$ \\
\hline Teen/total births (t-25) & $\begin{array}{l}1.38 \\
(2.76)\end{array}$ & $\begin{array}{l}5.53 \\
(3.35)\end{array}$ & $\begin{array}{l}-2.80 \\
(3.29)\end{array}$ & $\begin{array}{l}-2.77 \\
(5.71)\end{array}$ \\
\hline Gini & $\begin{array}{l}1.36 \\
(1.27)\end{array}$ & $\begin{array}{l}0.61 \\
(2.09)\end{array}$ & $\begin{array}{l}2.82 \\
(2.43)\end{array}$ & $\begin{array}{l}0.58 \\
(2.57)\end{array}$ \\
\hline Difficulty firing worker & $\begin{array}{l}0.14 \\
(0.34)\end{array}$ & $\begin{array}{l}0.11 \\
(0.50)\end{array}$ & $\begin{array}{l}0.05 \\
(0.52)\end{array}$ & $\begin{array}{l}-0.23 \\
(0.75)\end{array}$ \\
\hline Unemployment rate & $\begin{array}{l}2.77 \\
(1.82)\end{array}$ & $\begin{array}{l}3.12 \\
(2.77)\end{array}$ & $\begin{array}{l}0.76 \\
(2.15)\end{array}$ & $\begin{array}{l}-0.20 \\
(4.29)\end{array}$ \\
\hline Observations & 183 & 88 & 92 & 96 \\
\hline Joint $p$-value & 0.000 & 0.000 & 0.000 & 0.009 \\
\hline
\end{tabular}

Robust standard errors in parentheses. Dependent variables in logs.

Missing data on indep. variables multiply imputed. 